\title{
Bryozoan metabolites: an ecological perspective
}

\author{
Jasmine H. Sharp, Michael K. Winson and Joanne S. Porter* \\ Received (in Cambridge, UK) 7th February 2007 \\ First published as an Advance Article on the web 30th April 2007 \\ DOI: $10.1039 / \mathrm{b} 617546 \mathrm{e}$
}

Covering: 1980-2006

This Highlight covers the chemical ecology of bryozoans, primarily the ecological functions of bryozoan natural products. The Highlight is arranged taxonomically, according to the bryozoan Treatise classification (P. Bock, Bryozoa Homepage, 2006, http://bryozoa.net).

\section{Introduction}

\section{Background}

Historically, the study of natural products has focused on the biosynthetic pathways of terrestrial plants and micro-organisms, particularly the Actinomycetes. ${ }^{1}$ Terrestrial habitats have been screened extensively in order to find producers of natural products

Institute of Biological Sciences, University of Wales Aberystwyth, Aberystwyth, Ceredigion, Wales, UK. E-mail: jop@aber.ac.uk; Fax: +44 (0)1970 622350; Tel: +44 (0) 1970628667 with novel activities. The diversity of soil micro-organisms has been exploited for many years and most natural products of economic value, such as antibiotics, have been derived from this source. The number of novel natural products has decreased significantly in recent years largely because of the high rediscovery frequency encountered in screening programmes where standard microbial cultivation techniques are being used., ${ }^{2,3}$ This is of particular concern because the rapid increase in microbial resistance to antibiotics has serious implications for the prevention and treatment of disease. ${ }^{4}$ It is imperative, therefore, that the search for novel active compounds incorporates unexplored habitats and an

Jasmine H. Sharp completed her BSc in Marine \& Freshwater Biology at the University of Wales Aberystwyth in 2004. She is currently pursuing a PhD in marine biology with Joanne Porter and Michael Winson at the University of Wales Aberystwyth, investigating interactions between bryozoans and micro-organisms. Jasmine's research interests include microbial community ecology, particularly spatial and temporal changes in microbial interactions with marine Bryozoa.

Michael K. Winson is currently a lecturer in Molecular Microbiology at the Institute of Biological Sciences, University of Wales Aberystwyth. He received his BSc from the University of Wales Aberystwyth in 1987 and his PhD from the University of Wales Bangor in 1991. Michael's research interests include the control of gene regulation in microbial quorum sensing and the development of bacterial bioluminescent sensors for screening compound libraries for novel antibacterial and quorum sensing inhibitory compounds.

Joanne S. Porter is currently a lecturer in Marine Biology \& Bioinformatics at the Institute of Biological Sciences, University of Wales Aberystwyth. She received her BSc from the University of Newcastle-upon-Tyne in 1994 and her PhD from the University of Wales Swansea in 1999. Jo's research interests are focused around the phylum Bryozoa, including genetics and dispersal, phylogeography and phylogenetics. Recently she has been studying the chemical ecology of marine Bryozoa and their symbionts using a range of approaches including anti-microbial assays, larval settlement choice experiments, DGGE profiling and extract screening.

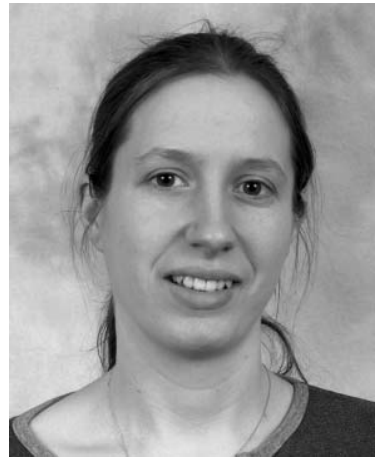

Jasmine H. Sharp

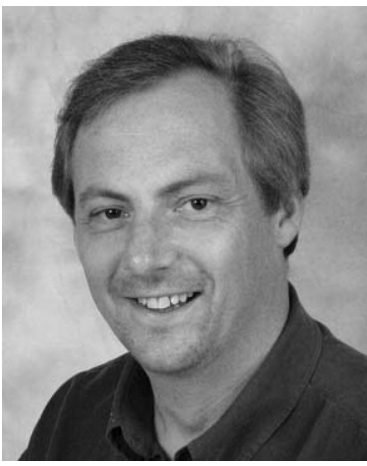

Michael K. Winson

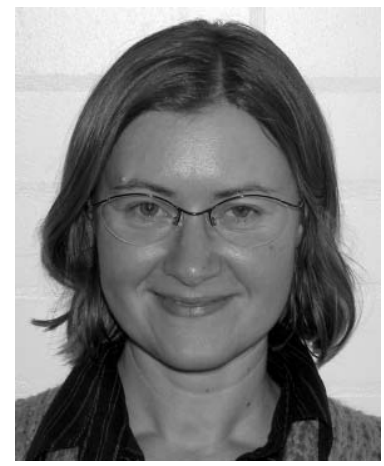

Joanne S. Porter 
extensive range of species from varied environments. These issues have led to the search for novel natural products being widened to encompass the flora and fauna of marine habitats. ${ }^{5,6}$

This Highlight will focus on marine fauna belonging to the phylum Bryozoa. The majority of research into marine metabolites has centred on algae and sponges, although there is now increasing emphasis on investigating other phyla from this environment. Since $1986^{7}$ the annual Royal Society of Chemistry Marine Natural Products reviews have described a large number of marine metabolites from the published literature of the preceding year. ${ }^{6}$ In the 2004 annual review ${ }^{5}$ the highest numbers of novel compounds were isolated from sponges, followed by coelenterates and then microorganisms. In contrast, the lowest number of novel compounds was isolated from the phylum Bryozoa. Although over 8000 species are known, and having featured in the Marine Natural Products review every year, only $1 \%$ of natural products characterized so far are from Bryozoa. ${ }^{8}$

In this Highlight we will focus on research into the chemical ecology of marine bryozoans, an area that appears to be significantly under-investigated considering the ubiquitous nature and large number of species of bryozoans living in the marine environment. The importance of the ecological context has been somewhat neglected with much of the research having centred mainly on the isolation and structural characterisation of bryozoan natural products (over 70 studies).

There have only been two reviews specifically covering bryozoan metabolites since $1978,{ }^{9,10}$ the most recent of these being in $1990 .^{10}$ Significant progress has been made in the area since then, with particular emphasis being placed on research into the functionality of bryozoan secondary metabolites.

\section{Bryozoans}

Bryozoans, also known as sea mats or sea mosses, are found in both freshwater and marine environments. Freshwater bryozoans will not be discussed in this Highlight, principally because no natural products have been reported from them. Over 8000 species of Bryozoa have been described ${ }^{11}$ and with new taxa being discovered regularly this number is likely to increase in the next decade.

Historically, bryozoan taxonomy has been based on morphological characteristics. The basic body plan consists of a polyp, protected by a gelatinous or calcareous box termed a zooid; many zooids are integrated together to form the colony. Bryozoa are sessile filter-feeders and food is collected via a circle of ciliated tentacles (the lophophore). Reproduction occurs sexually by means of a dispersive larval stage, or by asexual fission of colony fragments. ${ }^{12}$ Due to the sessile nature of the colonies they are found in a variety of marine habitats, including rock and coral reefs, boulder communities and current-swept cobble areas, as well as man-made environments such as pier legs and ship hulls. These colonial marine invertebrates have long been regarded as key components of marine environments, hosting whole communities of micro-organisms and small invertebrates within their colony structures. ${ }^{13}$ Bryozoans produce chemicals for a variety of uses, including antifouling and antipredation..$^{14,15}$

There are three major classes within the phylum Bryozoa. The Phylactolaemata comprises exclusively freshwater Bryozoa. Stenolaemata is an exclusively marine class containing four orders, of which only one includes living species: order Cyclostomata.
Finally, the Gymnolaemata is a predominantly marine class containing two orders: Cheilostomata and Ctenostomata. ${ }^{16}$ Natural products and biological activity have been reported in all three Recent bryozoan orders. However, the majority of published reports focus on a few closely related species from a single order.

This Highlight has been organised systematically, grouping similar species within their major taxonomic groups. It is important to recognise that bryozoan taxonomy is revised continually and that the taxonomic grouping used does not necessarily represent the phylogenetic relationships between species. Owing to the complexity of the relationship between morphological and phylogenetic classifications, comparisons between species within a group can be useful, but species that are not listed together are not necessarily phylogenetically distant.

\section{Cyclostome bryozoans}

The order Cyclostomata represents the only living group within the class Stenolaemata, the other four orders are only seen as fossils. Cyclostome bryozoans are notable for the presence of brood chambers, or gonozooids, which appear as conspicuous swollen regions. These bryozoans tend to form erect colonies, or lobed, discoid or hemispherical encrustations. ${ }^{17}$

Only two species within the cyclostome bryozoans have known metabolites. This may seem surprising, as it is a larger group than the ctenostome bryozoans, which, in comparison, have four times as many species with described metabolites or chemical activity. However, the absence of work in this area reflects the general lack of research into the cyclostomes due to the taxonomical difficulties with the group. Cyclostome bryozoan identification often relies on features of the gonozooids, which are only present during reproductive periods.

Both of the cyclostomes with described natural products were investigated in the same study. Diaperoecia californica (D'Orbingy) was found to produce phidolopin $\mathbf{1}$, desmethyl phidolopin $\mathbf{2}$ and 3-nitro-4-hydroxybenzyl alcohol 3. ${ }^{18}$ Heteropora alaskensis (Borg) also contained 3-nitro-4-hydroxybenzyl alcohol 3. These two bryozoans are not closely related, belonging to separate suborders. Similar natural products were also found in several cheilostome bryozoans, including Phidolopora pacifica. The presence of these similar nitrophenols occurring in several seemingly unrelated bryozoans might indicate that the nitrophenols are of microbial origin. ${ }^{18}$
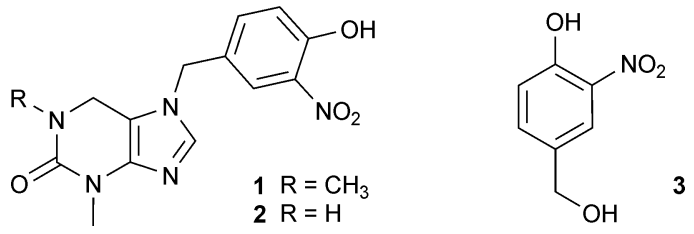

\section{Ctenostome bryozoans}

Within the class Gymnolaemata, there are two orders: the Cheilostomatida, which comprises the majority of living bryozoans, and the much smaller group, the Ctenostomatida. Ctenostome bryozoans are easily distinguished from other bryozoan orders by their lack of calcification, thus colonies appear membranous or gelatinous. Relatively few ctenostome bryozoans have 
documented chemical ecology. However, this may be partially due to the small size of the group.

\section{Suborder Alcyonidiina}

Only two families within the ctenostomes have been described in terms of their chemical ecology. The first family is the Alcyonidiidae. Two species within the genus Alcyonidium will be considered here. Alcyonidium diaphanum (Hudson) produces a sulfoxonium ion known to cause the allergic dermatitis, Dogger Bank Itch. ${ }^{19,20}$ This activity was first described in 1980, when the (2-hydroxyethyl)-dimethylsulfonium ion $\mathbf{4}$ was isolated and subsequently synthesised. ${ }^{20}$ Dogger Bank Itch is a serious and debilitating illness affecting some fishermen caused by overexposure to $A$. diaphanum, which is often brought up as bycatch. ${ }^{21,22}$ The subsequent skin sensitization results in dermatitis and, in acute cases, vesiculation and swelling of the arms and legs may occur. $^{23,24}$ The genus Alcyonidium has been subject to extensive reclassification and it is important to note that the causative agent of Dogger Bank Itch was found in the erect Alcyonidium gelatinosum, subsequently reclassified as $A$. diaphanum, which should not be confused with the encrusting A. gelatinosum (L). ${ }^{25,26}$ A. diaphanum is rare intertidally, found only in locations characterised by tidal rapids, but is widely distributed sublittorally in British fishing areas ${ }^{27}$ and is known to be an important habitat for breeding fish. ${ }^{28}$

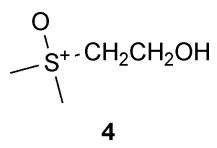

A second species within the genus Alcyonidium, Alcyonidium nodosum O'Donoghue \& Watteville, has been shown to inhibit predation from the rock lobster, Jasus lalandii (Milne Edwards). ${ }^{29}$ $A$. nodosum is an encrusting species, living largely on the shells of the whelk, Burnupena papyracea (Bruguiere). A. nodosum has been credited with ensuring the survival of $B$. papyracea by preventing predation of the whelk by the rock lobster. Whilst there is some physical protection afforded by the encrusting bryozoan, bioassays demonstrate that the feeding inhibition is principally chemical, although the compound responsible has not been isolated.

\section{Suborder Vesicularina}

Natural products have been described from several members of the family Vesiculariidae. Zoobotryon verticullatum della Chiaje is known to produce 2,5,6-tribromo- $N$-methylgramine 5, and the related side chain $N$-oxide $6{ }^{30}$ in addition to 2,5,6-tribromo- $N$ methylindole-3-carbaldehyde $7 .^{31}$ The first of these compounds has been shown to inhibit cell division and 2,5,6-tribromo- $N$ methylindole-3-carbaldehyde 7 is known to delay metamorphosis of sea urchin eggs. It also inhibits the condensation of chromatin, nuclear envelope breakdown and the assembly of the mitotic spindle, hence inhibiting cell division by preventing mitosis. ${ }^{32}$ The ecological implications of these activities are not known, but could relate to the prevention of invertebrate fouling on the bryozoan surfaces.<smiles>CN(C)Cc1c(Br)n(C)c2cc(Br)c(Br)cc12</smiles><smiles>Cn1c(Br)c(C[N+](C)(C)O)c2cc(Br)c(Br)cc21</smiles><smiles>Cn1c(Br)c(C=O)c2cc(Br)c(Br)cc21</smiles>

The related species, Zoobotryon pellucidum Ehrenberg, produces a very similar compound, 2,5,6-tribromo-1-methylgramine 8, which inhibits larval settlement of the barnacle Balanus amphitrite (Darwin) and the mussel Mytilus edulis (L). ${ }^{33}$ The similarity between the compounds in the genus Zoobotryon suggests similar function, likely to be the prevention of the settlement of other invertebrates either on or in the immediate vicinity of the bryozoan. This is of importance to the bryozoan as competition for space can be extremely high amongst sessile marine invertebrates, and fouling of the surface may be highly detrimental to the survival of sessile organisms. ${ }^{34,35}$<smiles>CN(C)Cc1c(Br)n(C)c2cc(Br)c(Br)cc12</smiles>

A second genus within the Vesicularidae, Amathia, has a number of species reported to produce bioactive metabolites. Amathia convoluta Lamarck has been found to contain bryostatins 4 6 9-11 and bryostatin $812 .{ }^{36}$ The bryostatins are a group of compounds usually associated with Bugula neritina (L). However, their production by $A$. convoluta cannot be confirmed due to the presence of $B$. neritina growing epiphytically on the sampled colonies. The issue of primary production of the bryostatins is further complicated as B. neritina itself may not be the primary producer of the bryostatins (see Cheilostomes). In addition to the bryostatins, several other groups of compounds have been reported in Amathia convoluta, including amathamide G 13, ${ }^{37}$ convolutamides A-F 14-19, ${ }^{38}$ convolutamines A-H 20-27, ${ }^{39-41}$ convolutamydines A-E 28-32, ${ }^{41-43}$ convolutindole A 33, ${ }^{39}$ and volutamides A-E 34-38. ${ }^{44}$ The biological activity of several of these compounds has been described, although this is mostly limited to descriptions of cytotoxicity against human cancer cell lines. These compounds include convolutamides A 14 and B 15 in combination, convolutamines A 20, B 21, D 23 and F 25, and convolutamydines A 28 and B 29. From a clinical view, this is interesting because it potentially leads to new drug target leads. It is also interesting from an ecological perspective because the ecological function of such chemicals is unknown, although Pettit has previously suggested that marine invertebrates are not known to have cancerous growth, ${ }^{45}$ and therefore these compounds may directly protect them from tumour growth.

Other metabolites of $A$. convoluta have additional properties. For example, convolutamine F $\mathbf{2 5}$ also inhibits cell division, 


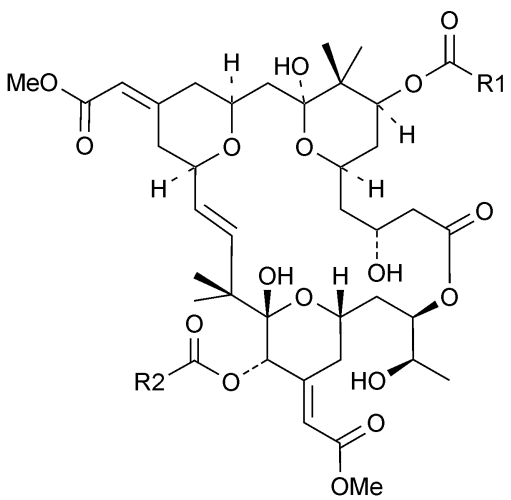

$9 \mathrm{R} 1=\mathrm{C}\left(\mathrm{CH}_{3}\right)_{3}, \mathrm{R} 2=\mathrm{CH}_{2} \mathrm{CH}_{2} \mathrm{CH}_{3}$

$10 \mathrm{R} 1=\mathrm{C}\left(\mathrm{CH}_{3}\right)_{3}, \mathrm{R} 2=\mathrm{CH}_{3}$

$11 \mathrm{R} 1=\mathrm{CH}_{2} \mathrm{CH}_{2} \mathrm{CH}_{3}, \mathrm{R} 2=\mathrm{CH}_{3}$

$12 \mathrm{R} 1=\mathrm{CH}_{2} \mathrm{CH}_{2} \mathrm{CH}_{3}, \mathrm{R} 2=\mathrm{CH}_{2} \mathrm{CH}_{2} \mathrm{CH}_{3}$<smiles>COc1c(Br)c(Br)c(Br)c(/C=C/N(C)C(=O)C2CCCN2C)c1OC</smiles><smiles>[R]c1cc(Br)c(CCN([R2])CC(C)O)c(Br)c1OC</smiles>

$20 \mathrm{R} 1=\mathrm{Br}, \mathrm{R} 2=\mathrm{CH}_{3}$ $21 \mathrm{R} 1=\mathrm{H}, \mathrm{R} 2=\mathrm{CH}_{3}$ $22 \mathrm{R} 1=\mathrm{Br}, \mathrm{R} 2=\mathrm{H}$

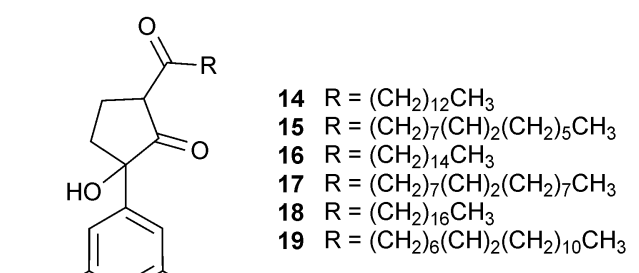

$15 \mathrm{R}=\left(\mathrm{CH}_{2}\right)_{7}(\mathrm{CH})_{2}\left(\mathrm{CH}_{2}\right)_{5} \mathrm{CH}_{3}$

$\mathrm{R}=\left(\mathrm{CH}_{2}\right)_{14} \mathrm{CH}_{3}$

$18 \mathrm{R}=\left(\mathrm{CH}_{2}\right)_{16} \mathrm{CH}_{3}$

$\mathrm{R}=\left(\mathrm{CH}_{2}\right)_{6}(\mathrm{CH})_{2}\left(\mathrm{CH}_{2}\right)_{10} \mathrm{CH}_{3}$<smiles>COc1c(Br)cc(Br)c(CCN2CC(C)OC(C)(O)C2)c1Br</smiles><smiles>[R]Cc1c([R3])c(Br)c(CCNC)c([R])c1OC</smiles>

列 $1=\mathrm{Br}, \mathrm{R} 2=\mathrm{Br}, \mathrm{R} 3=\mathrm{H}$ $26 \mathrm{R} 1=\mathrm{H}, \mathrm{R} 2=\mathrm{Br}, \mathrm{R} 3=\mathrm{H}$ $27 \mathrm{R} 1=\mathrm{Br}, \mathrm{R} 2=\mathrm{OCH}_{3}, \mathrm{R} 3=\mathrm{Br}$

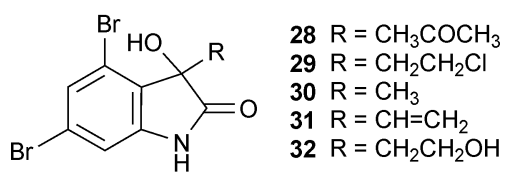<smiles>COc1c(Br)cc(Br)c2c(CCN(C)C)c(Br)n(OC)c12</smiles>

33<smiles>COc1cc(CCN(C)CCCNC(C)=O)c(Br)cc1Br</smiles><smiles>[R]P[R3]#[R]C</smiles><smiles>COc1ccc(CC(C(=O)N(C)CCc2cc(OC)c(Br)cc2Br)N(C)C)cc1Br</smiles><smiles>COc1ccc(CC(C(=O)NCCCN(C)CCc2cc(OC)c(Br)cc2Br)N(C)C)cc1Br</smiles>

which, as described above, could potentially prevent the growth of other species in the immediate vicinity. Volutamides B 35 and C 36 inhibit pinfish (Lagodon rhomboids (L.)) feeding by up to $93 \%{ }^{44}$ whilst volutamides B 35 and D 37 are toxic to the larvae of the co-occurring hydroid Eudendrium carneum Clarke. ${ }^{44}$ Inhibition of feeding of a potential predator has an obvious ecological importance in that it prevents the bryozoan being eaten. The toxicity to hydroid larvae is also of important ecological consequence due to the competition for space between sessile organisms. In this way, an established bryozoan colony might prevent the settlement of adjacent hydroids competing for space and food resources.

More recently, convolutamine H 27 and convolutindole A 33 were found to exhibit nematocidal activity against the free living larval stage of the parasitic nematode Haemonchus contortus (Rud). ${ }^{39}$ Although the benefits of deterring potential parasites are clear, $H$. contortus parasitises sheep and ruminants, not bryozoans. Therefore, this discovery has potential clinical use, as the potency of these two compounds is greater than commercially available products. The principal ecological function of these compounds is currently unclear, although Narcowicz et al. ${ }^{39}$ suggested that convolutamine H 27 may be the precursor to amathamide G 13 .

Although there are a very large number of different natural products described in $A$. convoluta, later studies have failed to find metabolites described in the same species from different sites. Natural products from $A$. convoluta have been described from the Gulf of Mexico, the Atlantic coast in North Carolina, and Southern Tasmania, although different products have been found in each of these areas. Narcowicz et al..$^{39}$ propose that this variability occurs because some of the metabolites are produced by bacterial symbionts and the variability arises from mutation within the bacterial strain. However, there is no conclusive evidence to support this hypothesis. It is possible that different metabolite production could be caused by a number of factors, including differing environmental pressures.

Amathia convoluta is not the only species of the genus Amathia containing described natural products. Amathia wilsoni Kirkpatrick, studied in Tasmania, has been found to contain two major groups of molecules, the amathaspiramides A-F $\mathbf{3 9}-\mathbf{4 4}^{46}$ and the amathamides $\mathbf{4 5 - 5 0} .^{47,48}$ It has been suggested that the synthesis 
pathway involves 2-(2,4-dibromo-5-methoxyphenyl)ethanamine, discovered in A. wilsoni in $1989 .{ }^{49}$

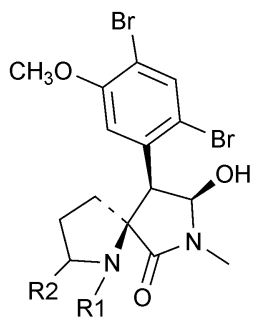

$39 \mathrm{R} 1=\mathrm{CH}_{3}, \mathrm{R} 2=\mathrm{H}$

$40 \mathrm{R} 1=\mathrm{CH}_{3}, \mathrm{R} 2=\mathrm{O}$

$41 \mathrm{R} 1=\mathrm{H}, \mathrm{R} 2=\mathrm{H}$

$42 \mathrm{R} 1=\mathrm{H}, \mathrm{R} 2=\mathrm{O}$<smiles>[R2]c1c(Br)c(/C=C/N([R1])C(=O)C2CCCN2C)cc(OC)c1Br</smiles>

$45 \mathrm{R} 1=\mathrm{H}, \mathrm{R} 2=\mathrm{H}$ $47 \mathrm{R} 1=\mathrm{CH}_{3}, \mathrm{R} 2=\mathrm{Br}$ $49 \mathrm{R} 1=\mathrm{H}, \mathrm{R} 2=\mathrm{Br}$<smiles>COc1cc([C@H]2[C@@H](O)N(C)C(=O)[C@@]23CCC=N3)c(Br)cc1Br</smiles>

43

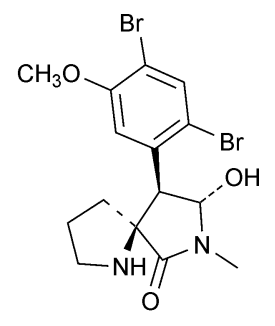

44<smiles>[R]c1c(Br)c(/C=C\NC(=O)C2CCCN2C)cc(OC)c1Br</smiles><smiles>COc1cc(CCNC(=O)C2CCCN2C)c(Br)cc1Br</smiles>

A. wilsoni has been the subject of extensive ecological studies. The amathamide content of $A$. wilsoni varies between sampling sites, but individual sites remain constant over time, exhibiting no seasonal variation or individual colony variation..$^{47}$ In addition, the distribution of the amathamides within individual colonies decreases from the colony tip $(9 \%)$ to the base, with the basal areas being totally devoid of metabolites. ${ }^{50}$ Interestingly, exposed tips at the periphery of the colony were found to contain higher total alkaloid levels than tips from the colony interior. Although the function of such a gradient is unknown, Walls et al. ${ }^{50}$ suggested that new growth would be more susceptible to predation and larval settlement, the latter due to the decrease in spatial competition. Therefore, enhanced chemical defence in these areas could reduce grazing and fouling, although high metabolite content in one area does not necessarily indicate that metabolites are produced in these areas. Walls et al. ${ }^{51}$ suggest that the surface-associated bacteria may be responsible for the production of the amathamides. High bromine levels on the bryozoan surface, but not in the cells, indicate that the amathamides are present on the surface but are not found in the cells. The surface bromine distribution correlates with the presence of surface bacteria, suggesting that production is associated with these bacteria.

Although in previous studies it had been reported that there were differing amounts of amathamides from $A$. wilsoni collected in different Tasmanian sites, none had recorded an absence of amathamides. However, a study of $A$. wilsoni from New Zealand reported the presence of amathaspiramides $\mathrm{A}-\mathrm{E}$ but no amathamides. ${ }^{46}$ The authors of this study suggest that the different chemical profiles reflect genetic variability or differing environmental conditions between the populations studied. This contrasts with the opinion of Narcowicz et al. ${ }^{39}$ who suggested that the difference in chemical profiles of the closely related species, $A$. convoluta, could be the result of bacterial symbionts producing the products associated with the bryozoan. There is currently no conclusive evidence as to which of these hypotheses is most likely to be a true representation of the situation.

Of the amathaspiramides found in the New Zealand A. wilsoni, only A 39 and E 43 exhibited activity in any of the assays used. These two compounds displayed moderate cytotoxicity to cancer cell lines and also mild antimicrobial activity against the Grampositive bacterium Bacillus subtilis and the fungus Trichophyton mentagrophytes. Antimicrobial activity could potentially prevent micro-fouling of the bryozoan zooids which is beneficial because micro-fouling organisms can attract macro-foulers. ${ }^{52}$ Both fouling types may prevent essential functions of the bryozoan colony including feeding and reproduction. ${ }^{53}$

Amathamide C 47, described from Tasmanian $A$. wilsoni, has also been described in Amathia pinnata Kirkpatrick, again from Tasmania. ${ }^{37}$ No additional biological activity was described, but it is interesting to note the presence of the same metabolite in two closely related species. A fourth species in the same genus, Amathia alternata, produces alternamides A-D 51-54, of which alternamides A-C 51-53 exhibited antibacterial activity against several Gram-positive bacteria including Staphylococcus aureus, B. subtilis and Enterococcus faecium. ${ }^{54}$ This activity could potentially prevent bacterial surface fouling or prevent infection by some bacteria.

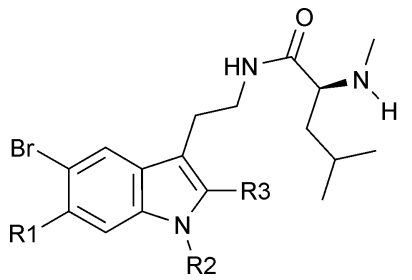

$51 \mathrm{R} 1=\mathrm{Br}, \mathrm{R} 2=\mathrm{CH}_{3}, \mathrm{R} 3=\mathrm{Br}$

$52 \mathrm{R} 1=\mathrm{Br}, \mathrm{R} 2=\mathrm{H}, \mathrm{R} 3=\mathrm{Br}$

$53 \mathrm{R} 1=\mathrm{H}, \mathrm{R} 2=\mathrm{H}, \mathrm{R} 3=\mathrm{Br}$

$54 \mathrm{R} 1=\mathrm{Br}, \mathrm{R} 2=\mathrm{H}, \mathrm{R} 3=\mathrm{H}$

There are several hundred species within the order Ctenostomata. Of these, only eight species have been documented to exhibit specific chemical activity, these falling into just two families. ${ }^{20,29-31,36-44,46-48,50,54,55}$ Even though very few species have been studied, those that have been studied exhibit a large range of natural products, often with interesting ecological functions, ranging from antimicrobial activity to feeding deterrents. Interestingly, all of the metabolites described from the two species within the genus Zoobotryon are similar. In contrast, the range of structures found within the genus Amathia is huge, even within the single species $A$. convoluta. With such a large number of natural products found in this very small number of species, ctenostomes thus represent an excellent target for future research.

\section{Cheilostome bryozoans}

Within the class Gymnolaemata, the largest order consists of the cheilostome bryozoans, distinguishable from ctenostome bryozoans by the presence of calcification of the frontal wall and distinguished from cyclostome bryozoans by the presence of a hinged operculum covering the zooid orifice and the presence of several different types of non-feeding heterozooids. ${ }^{11}$

Cheilostome bryozoans exhibit many different structural colony types, ranging from small short-lived laminar encrustations to large erect growths in unilaminar or bilaminar plates. This 
group of bryozoans contains many species for which natural products or chemical ecology have been documented, although many of these are closely related. As with the other bryozoan orders, taxonomic research is ongoing and classification changes are relatively frequent. This can lead to confusion regarding taxonomic identities arising when describing the chemical ecology of species. This illustrates the importance of ensuring that species identity is checked by an expert and that representative specimens are appropriately archived in a museum.

\section{Suborder Malacostega}

Within the family Membraniporidae, and within suborder Malacostega, there are two species of note. Biflustra perfragilis MacGillivray produces the isoquinoline quinones, perfragilin A 55 and perfragilin B 56. ${ }^{56,57}$ Both perfragilins exhibit cytotoxic activity to human cancer cell lines. The cytotoxicity of perfragilin B $\mathbf{5 6}$ is increased by the presence of a thiomethyl group, demonstrating that small structural changes can significantly alter the biological activity of a natural product. ${ }^{58}$ The structure of the perfragilins is similar to that of mimosamycin 57, isolated from the bacterium Streptomyces lavendulae. Mimosamycin has been documented in a number of organisms both terrestrial and marine. The similarity between the perfragilins and mimosamycin 57 has lead to the hypothesis that because mimosamycin in the marine environment is of bacterial origin, by extension the perfragilins are also of bacterial origin. ${ }^{57}$ This bryozoan species has been the subject of taxonomic confusion and is often referred to as Membranipora perfragilis rather than Biflustra perfragilis. The two genera in question are very closely related, but Biflustra is considered to be the correct classification. ${ }^{59}$ Due to this confusion, perfragilin B 56 appears to have been named twice. Blackman et $a{ }^{59}$ report the isolation of two isoquinoline quinones, 2methyl-6-methylthioisoquinoline-3,5,8(2H)-trione and 2-methyl6,7-di(methylthio)isoquinolone-3,5,8(2H)-trione 58, from an Australian specimen of Biflustra perfragilis. The former is identical in structure to perfragilin B 56. The second metabolite isolated, 2-methyl-6,7-di(methylthio)isoquinolone-3,5,8(2H)-trione 58, exhibited growth inhibition against several marine bacterial strains. ${ }^{59}$ It was also active in the brine shrimp assay, causing mortality at $3.5 \times 10^{-4} \mathrm{mmol}^{-1}$. The antibacterial activity is beneficial to the bryozoan by preventing bacterial colonization. Blackman et al. ${ }^{59}$ suggest that the activity of the metabolites of $B$. perfragilis is responsible for the low level of fouling on the bryozoan colony and also the lack of predation on an otherwise fragile species.<smiles>[R]C1=C(SC)C(=O)c2cc(=O)n(C)cc2C1=O</smiles>

$$
\begin{aligned}
55 \mathrm{R} & =\mathrm{NH}_{2} \\
56 \mathrm{R} & =\mathrm{SCH}_{3}
\end{aligned}
$$<smiles>COC1=C(C)C(=O)c2cc(=O)n(C)cc2C1=O</smiles><smiles>CSC1=C(SC)C(=O)c2cn(C)c(=O)cc2C1=O</smiles>

Several less complex compounds have been isolated from $B$. perfragilis. Methanol, dimethyl sulfide, dichloromethane, dimethyl disulfide, chloromethane and methanethiol have all been isolated from $B$. perfragilis and are genuine products, rather than artifacts of isolation, although the biosynthetic origin and function is unclear. ${ }^{60}$

A species closely related to $B$. perfragilis, Membranipora membranacea (L.), currently has no documented products. However, it displays an interesting aspect of chemical ecology. In the presence of certain predators, $M$. membranacea colonies produce large, and energetically expensive, defensive spines. ${ }^{61}$ The cue for this growth is now thought to be chemical, although the molecule responsible has not been isolated. ${ }^{62,63}$

\section{Suborder Neocheilostomina: Infraorder Flustrina}

The infraorder Flustrina, within suborder Neocheilostomina is a large group containing several species for which chemical ecology has been documented. Within the family Flustridae (Superfamily Flustroidea), there are four species to consider: Flustra foliacea L, Chartella papyracea Ellis \& Solander, Hincksinoflustra denticulata Busk and Securiflustra securifrons (Pallas).

Flustra foliacea is the most commonly studied bryozoan in terms of natural product research, both with respect to the number of individual metabolites described and the number of studies. The principal reasons for this are that $F$. foliacea is easily identifiable, known to many non-specialists as hornwrack, and particularly abundant, being found in large quantities in a range of different geographical locations. There are a large number of metabolites described from $F$. foliacea in a significant volume of literature. ${ }^{13,15,64-79}$ Unfortunately, many of these studies only describe the isolation and physical structure of a metabolite, without reference to activities that might be attributable to them, with regard to either their ecological function or potential commercial functions.

One of the first studies of bryozoan chemical ecology was the discovery that $F$. foliacea inhibits the growth of $S$. aureus. ${ }^{15}$ Interestingly, the highest antibacterial activity was observed in the older parts of the colony, with virtually no activity observed in the tips. The same study also showed that extracts of $F$. foliacea discouraged settlement of other invertebrate larvae. The characteristic lemon smell of this species is attributable to the presence of cis- and transcitral 59-60, along with citronellol 61, nerol 62 and geraniol $63 .{ }^{67}$ The functions of these chemicals in $F$. foliacea are not known, but citral and geraniol are well known chemical signalling molecules in terrestrial organisms such as bees. ${ }^{80}$

Other $F$. foliacea products include flustramines A-E 64$\mathbf{6 8},{ }^{64-66,68,72}$ flustraminols A $\mathbf{6 9}$ and B 70, ${ }^{66}$ flustrabromine 71, ${ }^{77}$ flustramides A 72 and B 73, ${ }^{71,78}$ 6-bromo- $N_{\mathrm{b}}$-methyl- $N_{\mathrm{b}}$ formyltryptamine $\mathbf{7 4},{ }^{78}$ 7-bromo-4-(2-ethoxyethyl)quinolone $\mathbf{7 5},{ }^{79}$ dihydroflustramine C $\mathbf{7 6}$ and its $N$-oxide $\mathbf{7 7 ,}{ }^{72,76}$ isoflustramine D $\mathbf{7 8},{ }^{72}$ flustramine $\mathrm{D} \quad \mathrm{N}$-oxide $\mathbf{7 9},{ }^{72}$ flustrarine $\mathrm{B} \mathbf{8 0},{ }^{71}$ debromoflustramine B $\mathbf{8 1},{ }^{68}$ 4,6-bis(4-methylpent-3-en-1-yl)6-methylcyclohexa-1,3-diene-1-carbaldehyde $\quad \mathbf{8 2 ,}{ }^{70}$ 6-bromo2-(1,1-dimethyl-2-propenyl)-1 $H$-indole-3-carbaldehyde $\mathbf{8 3}, \quad N$ (2-[6-bromo-2-(1,1-dimethyl-2-propenyl)-1 $H$-indol-3-yl]ethyl)- $N$ methylmethanesulfonamide 84, deformyl-flustrabromine $\mathbf{8 5}$ and $\left(3 \mathrm{a} R^{*}, 8 \mathrm{a} R^{*}\right)$-6-bromo-3a-[(2E)-3,7-dimethyl-2,6-octadienyl]$1,2,3,3 \mathrm{a}, 8,8 \mathrm{a}$-hexahydropyrrolo[2,3- $b]$-indol-7-ol $\mathbf{8 6} .{ }^{73}$ 


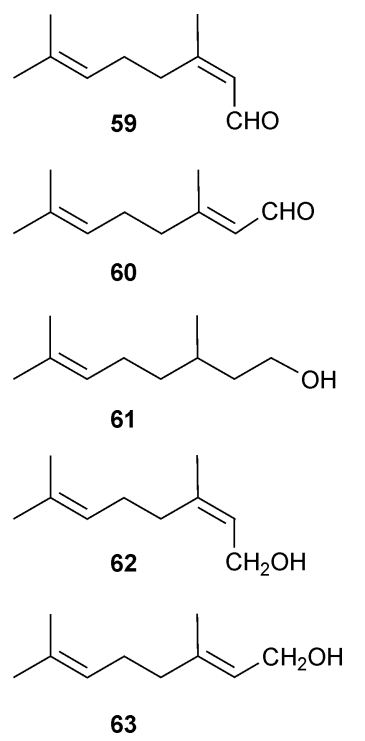

Of all of the above studies, only a handful are of specific interest for their biological activities. Flustramine E 68 exhibits antibiotic activity against a range of micro-organisms including B. subtilis, and the fungi Rhizoctonia solani, Fusarium oxysporum, Saccharomyces cerevisiae and Botrytis cinera. ${ }^{68}$ The species used to test for antifungal activity are standard testing species, and most are the causative agents of plant diseases. Although this could lead to novel fungicides, it seems unlikely that $F$. foliacea would need antifungal activity against these particular species. However, antifungal activity against a range of fungal species would prevent disease of the colony. Flustramine E 68 is structurally similar to pseudophrynaminol 87, previously isolated from the Australian frog, Pseudophryne coriacea Keferstein. This similarity adds weight to arguments that some bryozoan metabolites may not be bryozoan in origin. Flustramine D 67 also exhibits antimicrobial activity against Escherichia coli, Enterobacter cloacae, Serratia marcescens and Pseudomonas aeruginosa. ${ }^{72} \mathrm{~F}$. foliacea extracts are also known to have toxic effects on other invertebrate larvae, and fish. ${ }^{81}$

Later studies of $F$. foliacea have often failed to isolate metabolites found in previous studies. Part of this is likely to be associated with the isolation method. However, the isolation of some but not all closely related alkaloids, for example, indicates the variability of production. This seems to differ according to geographic location. For example, F. foliacea samples from the North Sea produce flustramine E 68, which has weak activity against B. subtilis, ${ }^{68}$ whereas Canadian samples have not been found to contain flustramine $\mathrm{E}$ 68, but do produce flustramine D 67, ${ }^{72}$ which has strong activity against $B$. subtilis. One hypothesis for this occurrence is that changes in environmental pressures between various geographical locations cause differential metabolite production. ${ }^{68}$

In the current decade there have been several important studies investigating the chemical ecology of $F$. foliacea including the variation in the presence of a number of $F$. foliacea natural products within and between colonies. In their geographical study, Peters et al. ${ }^{75}$ illustrated that $F$. foliacea from different geographical sites produces different metabolites. Sites that were close together yielded $F$. foliacea colonies with similar metabolite profiles, while distant colonies produced entirely different profiles, with different dominant metabolites and differing minor products. Temporal patterns of alkaloid production were also recorded. While the number and type of alkaloids did not change over time, the concentrations of individual metabolites fluctuated throughout the year. Within single colonies, the concentration of essential oils (e.g. nerol, geraniol etc.) increased from the tip to the base. However, alkaloid concentration remains stable throughout the colony. Peters et al. ${ }^{75}$ concluded that variation in metabolite production between colonies in different locations could be explained by one of three hypotheses. Firstly, F. foliacea at the different locations<smiles>C=C[C](C)[C@@]12c3ccc(Br)cc3N(CC=C(C)C)C1(C(C)(C)C=C)CCN2C</smiles><smiles>C=CC(C)(C)C12CC(=O)N(C)[C@H]1c1ccc(Br)cc1N2CC=C(C)C</smiles><smiles>CC(C)=CCN1c2cc(Br)ccc2C2(CC=C(C)C)CCN(C)[C@H]12</smiles><smiles>C=CC(C)(C)C12Nc3cc(Br)ccc3C1(O)CCN2C</smiles>

69<smiles>CC(C)=CCN1c2ccc(Br)cc2C2(CC=C(C)C)CC(=O)N(C)C12</smiles><smiles>C=CC(C)(C)C12CCN(C)C1=Nc1cc(Br)ccc12</smiles>

66<smiles>CC(C)=CCC12Nc3cc(Br)ccc3C1(O)CCN2C</smiles><smiles>C=CC(C)(C)c1[nH]c2ccccc2c1CCN(C)C=O</smiles>

71<smiles>CN(C=O)CCc1c[nH]c2cc(Br)ccc12</smiles> 
<smiles>CCOCCc1ccnc2cc(Br)ccc12</smiles>

75<smiles>C=CC(C)(C)C12CCN(C)C1Nc1cc(Br)ccc12</smiles>

76<smiles>C=CC(C)(C)C12CC[N+](C)(C)C1Nc1cc(Br)ccc12</smiles>

77<smiles>C=CC(C)(C)C12CCN(C)C1Nc1c2ccc(Br)c1CC=C(C)C</smiles><smiles>C=CC(C)(C)C12CC[N+](C)(C)C1Nc1cc(Br)c(CC=C(C)C)cc12</smiles>

79<smiles>C=CC(C)(C)c1[nH]c2cc(Br)ccc2c1C=O</smiles>

82

83<smiles>CC(C)=CCC/C(C)=C\C[C@]12CCN[C@H]1Nc1c2ccc(Br)c1O</smiles><smiles>C/C(=C\C12CCN(C)[C@H]1Nc1ccccc12)CO</smiles>

85

could represent separate subspecies of the bryozoan. Secondly, colonies at the different locations harbour different bacterial symbionts which are responsible for the production of some, if not all, of the detected metabolites. A third hypothesis is that secondary metabolite production is a reaction to the prevailing environmental conditions.

In addition to its bacteriocidal effects, $F$. foliacea produces compounds which have been shown to interfere with bacterial cell-cell communication, or 'quorum sensing. ${ }^{13}$ Many bacterial systems use such cell-cell communication to regulate a number of functions, including cell motility, virulence factors and biofilm formation..$^{82}$ Inhibition of quorum sensing systems, without bacteriocidal effects is beneficial because it prevents the establishment of infection or fouling without specifically blocking growth, hence there is no selection pressure on the bacterial cells, so no resistance arises. This effect is well known in marine algae but was previously unknown in bryozoans. ${ }^{83}$

A second species within the family Flustridae is Chartella papyracea. This species produces chartellines A-C 88-90, ${ }^{84,85}$ chartellamides A and B 91-92, ${ }^{86}$ and methoxydechlorochartelline

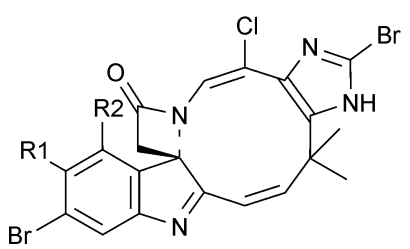

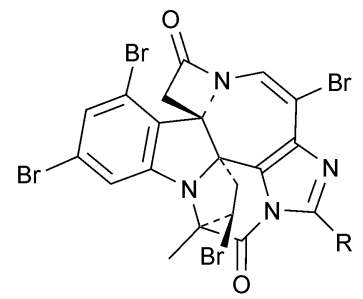

$88 \mathrm{R} 1=\mathrm{Br}, \mathrm{R} 2=\mathrm{Br}$ $89 \mathrm{R} 1=\mathrm{H}, \mathrm{R} 2=\mathrm{Br}$ $90 \mathrm{R} 1=\mathrm{H}, \mathrm{R} 2=\mathrm{H}$<smiles>[R][R]=[R]([R])Br</smiles>

A $93,{ }^{86}$ although the latter may be an artifact of isolation. All of these molecules are very similar; the chartellines differ only by the number of bromine substitutions.

Hincksinoflustra denticulata is also within the family Flustridae. A single metabolite has been isolated from this species: hinckdentine A 94. ${ }^{87}$ The final member of the Flustridae of note is Securiflustra securifrons, which produces securines A and B 9596, ${ }^{88}$ together with securamines A-G 97-103. ${ }^{88,89}$ As with the isolated products of C. papyracea, all of the metabolites of $S$. securifrons are structurally similar.<smiles>CC12C(=O)CC13Cc1cc(Br)ccc1N=CN3c1c(Br)cc(Br)cc12</smiles>

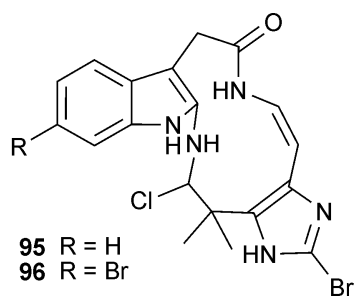<smiles>[R]c1ccc2c(c1)NC1C3CC(=O)C(/C=C\c4nc(Br)[nH]c4C(C)(C)C1(Cl)Cl)C23</smiles>

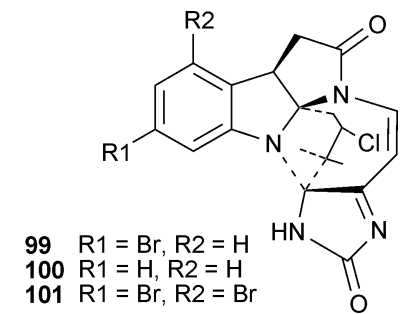<smiles>O=C1N=C2C=CN3C(=O)CC4c5ccc(Br)cc5N5C2(N1)C3(Cl)C45Cl</smiles>

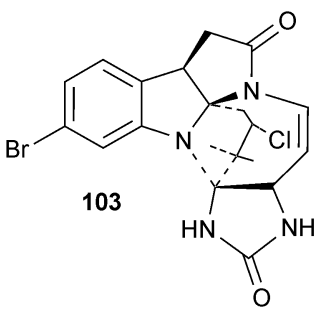


A second family within the infraorder Flustrina also has a large number of natural products and natural product research associated with it. The genus most well known for the production of natural products is Bugula, which belongs to the family Bugulidae (Superfamily Buguloidea). This genus is most well known for the production of the bryostatins. Research into the natural products of Bugula neritina (L.) has been ongoing since the isolation of bryostatin 1104 in $1982 . .^{90}$ Bryostatin $1 \mathbf{1 0 4}$ has been the focus of numerous subsequent studies to determine its biological, and specifically clinical, functions. When first isolated, bryostatin 1 104 was found to exhibit high levels of cytotoxic activity against P388 lymphocytic leukaemia and B16 melanoma. ${ }^{91}$ Bryostatin 1 104 is also known to both inhibit and stimulate the production of protein kinase $\mathrm{C},{ }^{92,93}$ promote normal bone marrow progenitor cell growth, ${ }^{94}$ and stimulate the production of interleukin $2 .{ }^{95}$ This area of bryozoan metabolite research is very extensive due to the interest in the clinical uses of the bryostatins, particularly due to their promising anti-cancer activity. There are several reviews of the clinical applications and properties of the bryostatins. ${ }^{45,96-98}$

Since the initial discovery of bryostatin $1 \mathbf{1 0 4}$, bryostatins 2-20 105-106, 9-11, 107, 12 \& 108-119 have also been described, ${ }^{99-109}$ including several re-designations. ${ }^{110-112}$ Due to its potential clinical applications, there has been significant interest in the large-scale production of bryostatin. However, bryostatin is found in very small amounts in B. neritina and the isolation of $18 \mathrm{~g}$ of bryostatin 1104 required the collection of 10000 gallons of $B$. neritina material. ${ }^{113}$ Bryostatin $1 \mathbf{1 0 4}$ may be synthesized from bryostatin 2 105. ${ }^{114}$ However, bryostatin 2105 must also be harvested from B. neritina. Therefore, although this can lead to increased yield because bryostatin 1104 can be harvested directly and bryostatin 2105 in the sample can be converted to bryostatin 1104 , total yield is still relatively small. More recently, aquaculture of $B$. neritina with the purpose of bryostatin production has been investigated. ${ }^{115}$ Using this system, $81 \mathrm{~g}$ of bryostatin $1 \mathbf{1 0 4}$ could be produced per year. In this aquaculture system, the environmental costs of harvesting would be decreased. However, the monetary cost of this system was $\$ 29000$ per gram of isolated bryostatin, and clinical applications of bryostatin isolated in this way would be proportionally costly.

Several bryozoan metabolites are speculated to be of bacterial origin. ${ }^{10}$ However, in most bryozoans, there is no proof of this occurrence. Unlike other bryozoan species, B. neritina has been shown to harbour bacterial symbionts which are responsible for the production of the bryostatins. ${ }^{116}$ The bacterium Endobugula sertula is responsible for the production of the bryostatins in $B$. neritina and can be found in both the adult and larval stage. ${ }^{116-118}$ Bryostatins found in $B$. neritina larvae cause the larvae to be unpalatable to predators, ${ }^{117,118}$ hence increasing the probability of the larvae's survival to metamorphosis. This provides the first documented example of a marine microbial symbiont providing defence for its host. ${ }^{14}$

Two distinct chemotypes have been recognized within $B$. neritina populations found at the same location. ${ }^{119}$ B. neritina with chemotype $\mathrm{O}$ is found exclusively at depths of $9 \mathrm{~m}$ or more and these colonies contain the bryostatins 1, 2 and/or 3. Chemotype $\mathbf{M}$ is found at depths shallower than $9 \mathrm{~m}$ and contains no bryostatin 1,2 , or 3 . The endosymbiont bacteria harboured by these chemotypes are distinct strains, and Davidson $\&$ Haygood hypothesized that the chemotype differences are due to the different strains of the bacterial symbiont, E. sertula, harboured by the two populations. ${ }^{119}$ It was also suggested that the different chemical profiles could indicate the presence of two sibling species.

Although $B$. neritina is known primarily for the production of the bryostatins, this species also produces a number of other secondary metabolites. Cholesterol was shown to be produced de novo by $B$. neritina, whilst eight other isolated sterols were assimilated from the diet. ${ }^{120} B$. neritina also produces neristatin 1 120, a macrocyclic lactone similar to the bryostatins. ${ }^{121}$ Like the bryostatins, neristatin 1 is active against the P388 leukaemia cell line, although exhibiting weaker activity.

Bugula dentata (Lamouroux), a species closely related to $B$. neritina, produces a blue antimicrobial pigment 121 which exhibits antibacterial activity against both Gram-negative and Grampositive bacteria. ${ }^{122}$ The same antimicrobial pigment has been isolated in the bacterium Serratia marcescens ${ }^{123}$ and an Australian ascidian. ${ }^{124}$ This casts doubt over the origins of synthesis of these molecules. Bugula dentata also produces tambjamines C, E and G-J 122-127. ${ }^{125}$ The tambjamines were originally described in the nudibranch Tambje abdere Farmer, and then in the bryozoan Sessibugula transluscens Osburn. ${ }^{126}$ Tambjamines E 122, G 123 and I 125 were found to cause mortality of the brine shrimp. Activity against other invertebrates may suggest a possible feeding deterrent mechanism.

Bugula pacifica inhibits the growth of a range of marine bacteria and also B. subtilis, E. coli and $S$. aureus. This activity may be responsible for the low degree of fouling on $B$. pacifica, although the causative agent is currently unknown. ${ }^{53}$

Other species of interest within the same family as $B$. neritina and $B$. dentata are Dendrobeania murrayana (Johnston), which produces murrayanolide 128, ${ }^{127}$ Caulibugula inermis Harmer, which produces the cytotoxic caulibugulones A-F 129-134, ${ }^{128}$ and Sessibugula translucens Osburn. Sessibugula translucens produces tambjamines A-D 135-136, 122 \& 137, of which A 135 and B 136 exhibit antimicrobial activity against B. subtilis, S. aureus, E. coli and Vibrio anguillarium, whilst C 122 and D 137 also exhibit activity against $V$. anguillarium, $S$. aureus and B. subtilis, in addition to Candida albicans. ${ }^{126}$ The tambjamines also prevent cell division of invertebrates. ${ }^{126}$ This activity may help prevention of micro- and macro-fouling, but provides no assistance against the nudibranch predator, Tambje abdere Farmer, which is able to assimilate the tambjamines from the bryozoan and use them for its own defence. ${ }^{126}$

Tricellaria ternata (Ellis \& Solander) (Superfamily Buguloidea, Family Candidae) is related to the Bugulidae. This species produces 4-methoxy-2-nitrophenol 138. A second, related species, Tricellaria occidentalis (Trask), exhibits antibacterial activity towards E. coli, S. aureus, B. subtilis and range of marine bacteria. The natural product responsible for this activity is not known, but is suggested to be responsible for control of microbial fouling. ${ }^{53}$

\section{Suborder Neocheilostomina: Infraorder Acanthostega}

Euthyroideones A-C 139-141 are produced by Euthyroides episcopolis (Busk). ${ }^{129}$ This cheilostome bryozoan is the only species within the family Euthyroididae (Infraorder Acanthostega, Superfamily Cribrilinoidia) from which natural products have been described. Euthyroideone B $\mathbf{1 4 0}$ exhibits weak cytotoxicity to the 

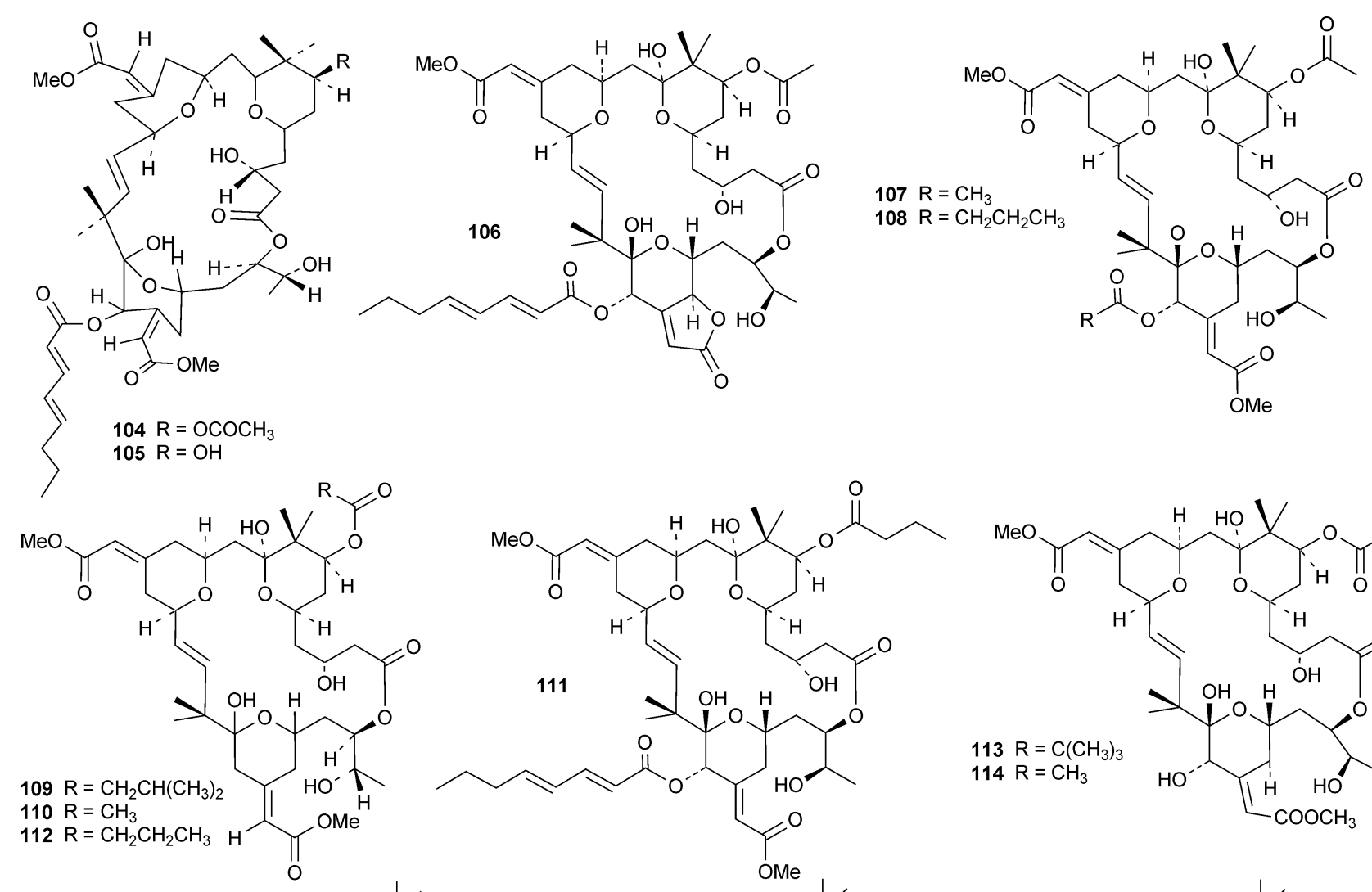<smiles>C/C=C\C(C)C/C(=C\C(=O)OC)CCCC(C)(C)C</smiles>

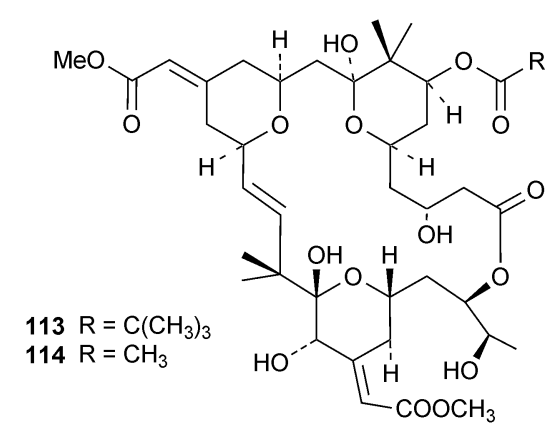

$110 \mathrm{R}=\mathrm{CH}_{3}$

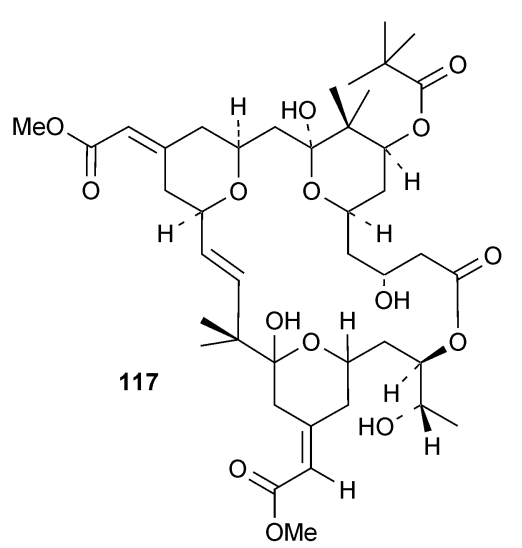

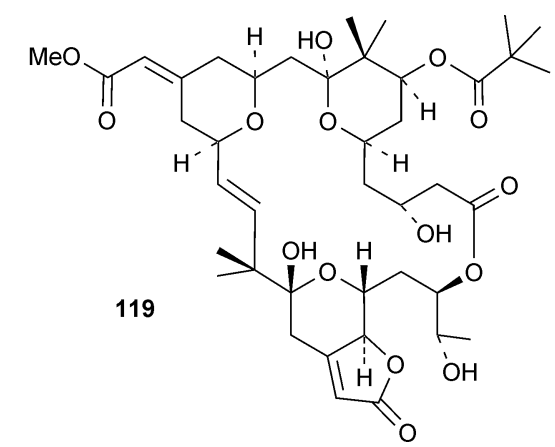

BSC-1 cell line. The euthyroideones are novel metabolites, but the underlying amine/sulfone substructure is similar to metabolites from marine sponges. ${ }^{130}$

Four species within the family Catenicellidae (Infraorder Acanthostega, Superfamily Catecelloidae) have known secondary metabolites. Pterocellins A and B 142-143, produced by Pterocella vesiculosa (Lamarck), are cytotoxic against the P388 and BSC1 cell lines. In addition, the pterocellins display antibacterial activity against $B$. subtilis and antifungal activity against $T$. mentagrophytes. 


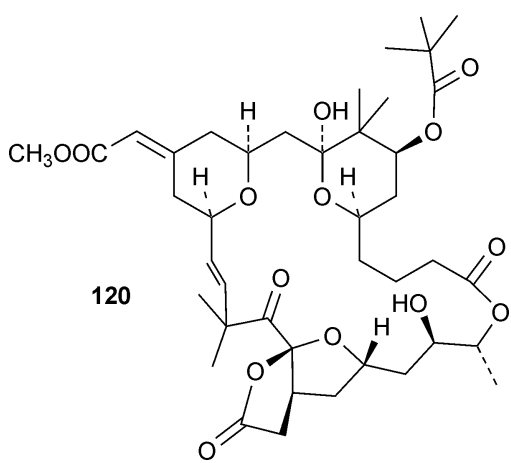

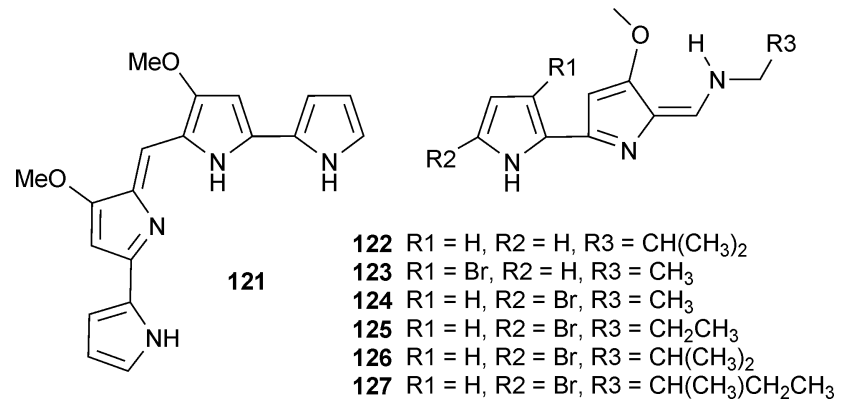

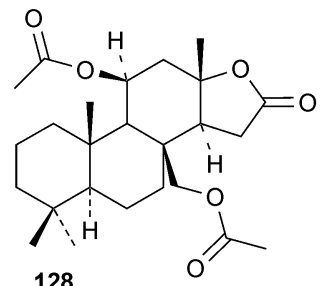<smiles>[R2]NC1=C([R])C(=O)c2ccncc2C1=O</smiles>

$129 \mathrm{R} 1=\mathrm{H}, \mathrm{R} 2=\mathrm{CH}_{3}$ $130 \mathrm{R} 1=\mathrm{Br}, \mathrm{R} 2=\mathrm{CH}_{3}$ $131 \mathrm{R} 1=\mathrm{Cl}, \mathrm{R} 2=\mathrm{CH}_{3}$ $132 \mathrm{R} 1=\mathrm{H}, \mathrm{R} 2=\mathrm{CH}_{2} \mathrm{CH}_{2} \mathrm{OH}$<smiles>[R]N=C1C=C(NC)C(=O)c2cnccc21</smiles><smiles>[R]c1ccc(C2=N/C(=C/N)C(OC)=C2)[nH]1</smiles><smiles>COC1=C/C(=C\NCC(C)C)N=C1c1[nH]ccc1Br</smiles><smiles>COCc1ccc(O)c([N+](=O)[O-])c1</smiles><smiles>CN1C=C2C(=C(Br)C(=O)C3=C2S(=O)(=O)CCN3)CC1</smiles>

139

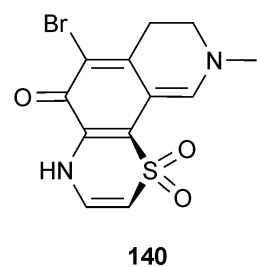<smiles>COc1cn2c(cc1=O)C(=O)c1ccnc(CC(C)C)c1-2</smiles><smiles>COc1cn2c(cc1=O)C(=O)c1ccnc(Cc3ccccc3)c1-2</smiles>

Three other species within the Catenicellidae produce similar metabolites. Costaticella hastata (Busk), Cribricellina cribraria Busk and Catenicella cribraria Busk all produce $\beta$-carbolines. ${ }^{131}$ The common compounds harman 144, 1-ethyl- $\beta$-carboline 145 and pavettine 146 have all been isolated from $C$. hastata, along with the novel $(S)-1-\left(1^{\prime}\right.$-hydroxyethyl)- $\beta$-carboline $147 .{ }^{131}$ Crude extracts of Cribricellina cribraria exhibit cytotoxicity against the P388 cell line and the NCI 60-cell tumour assay. Catenicella cribraria also exhibits cytotoxicity against the NCI 60-cell tumour assay. The activity of these species against the NCI 60-cell assay is due to the production of 1-vinyl-8-hydroxy- $\beta$-carboline 148 in both cases. ${ }^{132}$ Cribricellina cribraria also produces the cytotoxic $\beta$-carbolines harman 144, pavettine 146, 1 -ethyl- $\beta$-carboline 147, 1-ethyl-4-methylsulfone- $\beta$-carboline 149, homarine 150, 8hydroxyharman 151 and 6-hydroxyharman 152. ${ }^{133,134}$ The first four of these exhibit antimicrobial activity against the bacterium B. subtilis, and the fungi T. mentagrophytes, C. albicans and Cladisporum resinae. ${ }^{133}$ Activity against E. coli was also observed from harman 144 and pavettine 146. 6-hydroxyharman 152 was shown to exhibit anti-viral activity against Herpes simplex type I virus. ${ }^{134}$<smiles>[R]c1cccc2c1[nH]c1c([R1])ncc([R])c12</smiles>

$144 \mathrm{R} 1=\mathrm{CH}_{3} \mathrm{R} 2=\mathrm{H}, \mathrm{R} 3=\mathrm{H}$

$145 \mathrm{R} 1=\mathrm{CH}_{2} \mathrm{CH}_{3} \mathrm{R} 2=\mathrm{H}, \mathrm{R} 3=\mathrm{H}$

$146 \mathrm{R} 1=\mathrm{CHCH}_{2}, \mathrm{R} 2=\mathrm{H}, \mathrm{R} 3=\mathrm{H}$

$147 \mathrm{R} 1=\mathrm{CH}(\mathrm{OH}) \mathrm{CH}_{3}, \mathrm{R} 2=\mathrm{H}, \mathrm{R} 3=\mathrm{H}$

$148 \mathrm{R} 1=\mathrm{CHCH}_{2}, \mathrm{R} 2=\mathrm{OH}, \mathrm{R} 3=\mathrm{H}$

$149 \mathrm{R} 1=\mathrm{CH}_{2} \mathrm{CH}_{3}, \mathrm{R} 2=\mathrm{H}, \mathrm{R} 3=\mathrm{S}\left(\mathrm{O}_{2}\right) \mathrm{CH}_{3}$

$151 \mathrm{R} 1=\mathrm{CH}_{3}, \mathrm{R} 2=\mathrm{OH}, \mathrm{R} 3=\mathrm{H}$<smiles></smiles><smiles>Cc1nccc2c1[nH]c1ccc(O)cc12</smiles>

\section{Suborder Ascophora: Infraorder Lepraliomorpha}

The remaining cheilostome bryozoans all belong to the Infraorder Lepraliomorpha, in three different superfamilies. Myriapora truncata (Pallas) (Superfamily Schizoporelloidae, Family Myriaporidae) produces five 3 $\beta, 5 \alpha, 6 \beta$-trihydroxysterols including the novel compounds $(22 E, 24 R)$-24-methylcholesta-7,22-

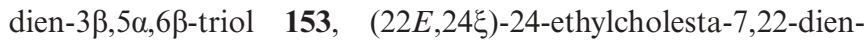
$3 \beta, 5 \alpha, 6 \beta$-triol 154 and (22E)-cholesta-7,22-dien-3 $\beta, 5 \alpha, 6 \beta$-triol 155. Activities for these compounds were not documented. ${ }^{135}$ 


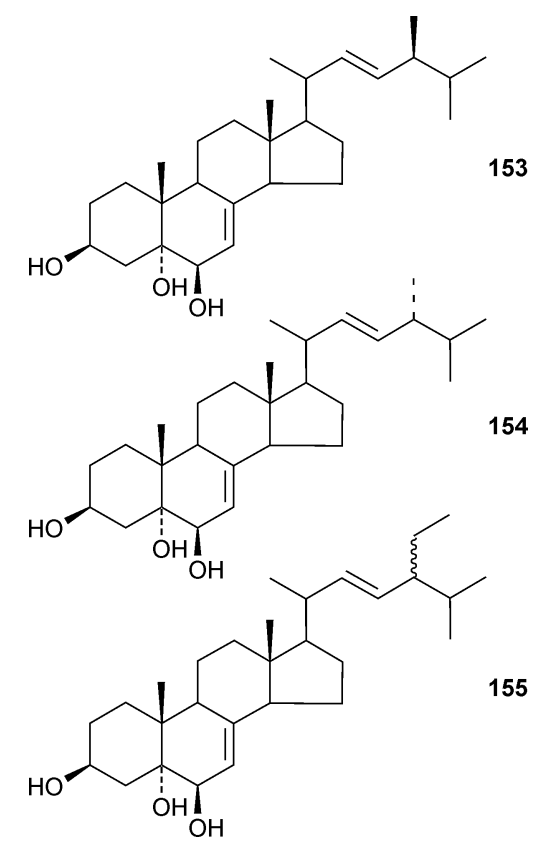

Four species within the superfamily Smittinoidea have had secondary metabolites documented. Three of these belong to the Genus Watersipora (Family Watersiporidae) and one belongs to the genus Pentapora (Family Bitectiporidae). Mediterranean colonies of Pentapora fascialis (Pallas) produce pentaporins AC 156-158. Crude extracts of $P$. fascialis exhibit antihelmintic activity against Trichinella spiralis (Owen) and the bioassay guided fractionation of this crude extract led to the isolation of the pentaporins. ${ }^{136}$ The ecological function of antihelmintic activity is currently unclear, but the activity may prevent predation by this group. Nematodes are also known to live in bryozoan colonies ${ }^{137}$ and so manipulation of these communities may be beneficial to the bryozoan.

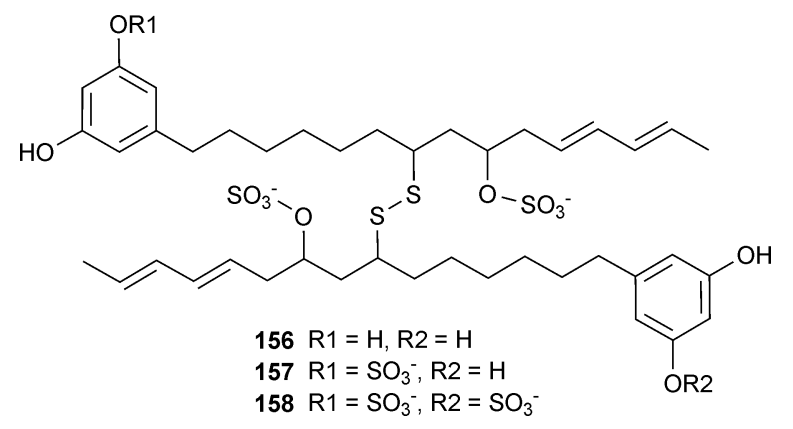

Watersipora cucullata (Busk) produces two ceramide-1-sulfates 159-160. ${ }^{138}$ This study represents the first example of the isolation of ceramide-1-sulfates as natural products. These two metabolites are inhibitors of the DNA topoisomerase I enzyme, which is a prime target for anticancer drugs. Dakaria subovoidea, now reclassified as Watersipora subovoidea (d'Orbigny) produces three natural products which inhibit lipid peroxide formation. ${ }^{139} 5,7-$ Dihydroxy-1-hydroxymethyl-6-oxo- $6 H$-anthra[1,9- $b c]$ thiophene 161 and its 1-methoxycarbonyl derivative 162 are novel compounds that were isolated with the known compound 1,8dihydroxyanthraquinone 163. A third species of Watersipora, Watersipora subtorquata d'Orbigny, also produces 5,7-dihydroxy1-methoxycarbonyl-6-oxo-6H-anthra[1,9-bc]thiophene 162 and 1,8-dihydroxyanthraquinone $\mathbf{1 6 3}$, together with the novel bryoanthrathiophene $164 .^{140}$

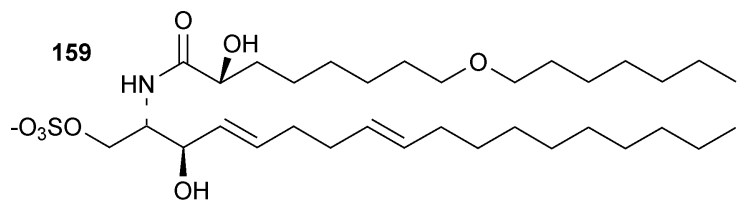<smiles>CCCCCCC/C=C/C(C)=C/CC/C=C/[C@@H](O)[C@@H](CO[Na])NC(=O)C(O)CCCCCCCCCCCCCCCC</smiles>

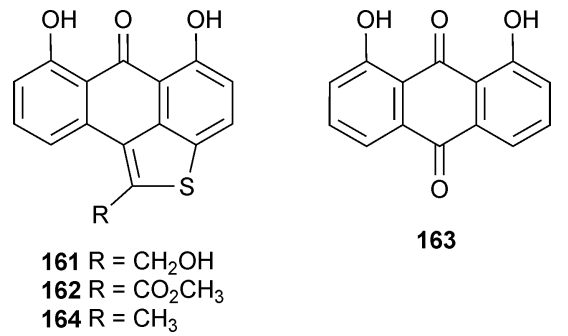

The final cheilostome bryozoan with interesting chemical ecology is Phidolopora pacifica (Robertson) (Superfamily Celleporoidae, Family Phidoloporidae). This bryozoan produces phidolopin 1, desmethyl phidolopin 2 and 3-nitro-4-hydroxybenzyl alcohol 3. ${ }^{18,141}$ However, Tischler et al. ${ }^{18}$ suggest the presence of these nitrophenols in a number of other species may be indicative of a microbial origin.

\section{Discussion}

The aim of this Highlight was to evaluate the range of studies that have been conducted in both natural product discovery and the chemical ecology of marine Bryozoa within a taxonomic framework.

It is interesting to note that in a phylum containing over 8000 species, only 32 of these have so far been studied from a natural products perspective, yielding approximately 200 compounds. Pre1990 , studies often focused solely on the isolation and description of the structural properties of bryozoan products rather than emphasising their ecological roles. More recently, focus has shifted towards studies on the biological activity of isolated metabolites, although this has often been in a pharmaceutical context. The expansion of research into clinical applications has led to a corresponding increase in the number of synthesis reports.

Our investigation of the published literature has revealed 32 species of bryozoans with documented natural products, distributed across 14 superfamilies. Many of these compounds are attributed to the same family or genus. There has been a significant bias towards studies of the Cheilostome infraorder Flustrina, compared with the suborders Inovicellina, Scruparia, and Malacostega. The reason for the low diversity of study species is likely to originate from taxonomic difficulties within the phylum. Historically, bryozoans were mistaken for plants, and are often found in herbarium collections in museums throughout the world. ${ }^{142}$ It is little surprise, then, that non-specialists seeking 
natural products may have difficulty recognising the phylum, let alone individual species.

The majority of bryozoan species with documented bioactivity are erect species which form complex and distinctive foliose shapes. These colony forms are not only easier to identify, but are also typically large. It is therefore easier to collect the volume of material required to extract natural products that exist within colonies at very low concentrations. ${ }^{113}$ It appears that very few encrusting bryozoan species have been the subject of natural product investigation. As these forms occupy different habitats and are subject to different environmental selection pressures, they may represent a new avenue for natural product discovery. For example, competition for space, both inter- and intra-specific, is more critical for encrusting species, where growth is strictly limited to available surfaces. The prevention of invertebrate settlement in the immediate area is likely to be of great benefit to the colony. Furthermore, it is logical to suggest that inhibitors of fish feeding are less likely to be encountered in encrusting species, compared to inhibitors that discourage the grazing activity of invertebrates such as molluscs.

A key question that has arisen from the studies of Bryozoa relating to the origin of the natural products is how many of these are actually produced by the Bryozoa and how many are produced by microbial endosymbionts? This topic was the subject of a review in $1990 .{ }^{10}$ There are examples to support the hypothesis that a number of natural products isolated from Bryozoa are not actually bryozoan in origin. The first of these is the similarity of many metabolites isolated from bryozoans to metabolites found elsewhere in the marine or terrestrial environments. Flustramines found in $F$. foliacea are similar to the skeleton of alkaloids produced by the Calabar bean, Physostigma venenosum, and flustramine E 68 is very similar to pseudophrynaminol 87 from the Australian frog, Pseudophryne coriacea. ${ }^{68}$ The perfragilins in Biflustra perfragilis are similar to mimosamycin 57, known from the terrestrial bacterium Streptomyces lavendulae. ${ }^{59}$ It has been argued that the lack of specificity of these metabolites suggests that they may actually be produced by symbiotic bacteria. Lack of specificity may also be explained by the transfer of metabolites to other organisms. The starfish Asterias rubens L. contains dihydroflustramine C 76, as do the snails Hydrobia ulvae (Pennant) and Gibbula cineraria (L.), which also contain flustramine A $64 .^{75}$ The tambjamines A-D 135-137 \& 122 found in the seaslug Tambje abdere are acquired from the seaslug's dietary source, the bryozoan Sessibugula translucens which harbours the primary producer Pseudoalteromonas tunicata. ${ }^{143}$ These tambjamines are used by the seaslug T. abdere as a defence chemical to deter the attack of the carnivorous seaslug Roboastra tigris, by making the slime trail of T. abdere unpalatable. ${ }^{144}$ It has also been reported that bryozoans assimilate products from their own dietary sources, as is the case with sterols assimilated by Bugula neritina. ${ }^{120}$

The geographic distribution of secondary metabolites of various species has been studied, with the presence of different geographical chemotypes being detected. ${ }^{114}$ One example of this showed that amathamides were isolated from Amathia wilsoni from Tasmania, compared with amathaspiramides which were isolated from New Zealand colonies. ${ }^{46,48}$ In comparison, in Bugula neritina, microbial chemotypes isolated from the same geographic location were vertically separated. These chemotypes harboured different strains of the symbiotic bacteria known to produce the bryostatins. ${ }^{119}$ The occurrence of these different geographical chemotypes is likely to be a product of environmental pressures specific to the location, or due to genetic variation between populations of the bryozoan species in question, therefore their distribution patterns merit further investigation.

Approximately 200 compounds have been described from bryozoans; most of the studies have been targeted towards a clinical or commercial development perspective. Fourteen bryozoan species produce compounds that are useful in the commercial context and one particular compound 'bryostatin' has 593 hits in a Pubmed search. The isolation and description of products with potential clinical applications is often the principal driver for research and funding, and relating the natural product to the ecological context is not a central purpose in many publications describing their isolation. This is illustrated by the example of the discovery that bryostatins are synthesized by symbiotic bacteria located inside $B$. neritina. The anti-cancer activities of bryostatin $1 \mathbf{1 0 4}$ have made it a highly desirable target for clinical applications, but it has only been possible to isolate gram amounts from 10000 gallons of field-collected material. ${ }^{113}$ Synthesis of bryostatin by a bacterium could potentially be of benefit in the future as it may facilitate production by microbial fermentation. Problems of raw material supply might therefore be overcome if symbiotic bacteria, or their genes, can be harnessed for the production of specific metabolites in the future. ${ }^{116}$ However there are problems associated with this approach. Inherent difficulties associated with culturing symbionts have limited progress so far, and the future may lie in developing improved techniques for culturing marine microbes or cloning biosynthetic clusters. ${ }^{143,145,146}$

\section{Conclusions}

There are a number of conclusions we can draw from this review of the bryozoan natural product literature. Relatively few bryozoan species have been studied from a natural products perspective (32) and those which have been studied belong to just 14 superfamilies. The majority of species studied to date are those with easily recognisable large, foliose colony morphologies. There is evidence to suggest that a number of the natural products described may not actually originate from Bryozoa themselves, but from endosymbiotic micro-organisms unique to Bryozoa. Therefore, it will be important in future studies to characterise the microbiota associated with Bryozoa. A key to understanding and furthering the study of the chemical ecology of bryozoans in the future will be through molecular biological studies using phylogenetic approaches. In the long term, the molecular approach may be necessary in order to avoid the replication problem which has confounded studies in other phyla. Modern molecular typing techniques can assist with the identification of bryozoan species, and may limit the rate of rediscovery to ensure dereplication of the same species from different habitats. To date, molecular approaches have been confounded by contamination from other taxa. However, as more genomic data become available, this situation is likely to improve. The development of novel specific primers as a result of the sequencing of the first bryozoan mitochondrial genome in 2006 is a significant breakthrough ${ }^{147}$ as is the cloning of biosynthetic clusters for production of useful products. $^{143}$ 


\section{References}

1 P. R. Jensen and W. Fenical, Annu. Rev. Microbiol., 1994, 48, 559-584. 2 R. Daniel, Curr. Opin. Biotechnol., 2004, 15, 199-204.

3 S. O. Duke, F. E. Dayan, J. G. Romagni and A. M. Rimando, Weed Res., 2000, 40, 99-111.

4 S. J. Projan and D. M. Shlaes, Clin. Microbiol. Infect., 2004, 10, 18-22. 5 J. W. Blunt, B. R. Copp, M. H. G. Munro, P. T. Northcote and M. R. Prinsep, Nat. Prod. Rep., 2004, 21, 1-49.

6 J. W. Blunt, B. R. Copp, M. H. G. Munro, P. T. Northcote and M. R. Prinsep, Nat. Prod. Rep., 2006, 23, 26-78.

7 D. J. Faulkner, Nat. Prod. Rep., 1986, 3, 1-33.

8 J. W. Blunt, B. R. Copp, M. H. G. Munro, P. T. Northcote and M. R. Prinsep, Nat. Prod. Rep., 2003, 20, 1-48.

9 C. Christophersen, Acta Chem. Scand., Ser. B, 1985, 39, 517-529.

10 U. Anthoni, P. H. Nielsen, M. Pereira and C. Christophersen, Comp. Biochem. Physiol., B: Biochem. Mol. Biol., 1990, 96, 431-437.

11 P. J. Hayward and J. S. Ryland, Cheilostomatous Bryozoa. Part I. Aeteoidea-Cribrilinoidea, Field Studies Council, Shrewsbury, 1998.

12 J. S. Ryland, in Moostiere (Bryozoa), ed. E. R. Wöss, Biologiezentrum, Linz, Austria, 2005, vol. 16, pp. 9-20.

13 L. Peters, G. M. Konig, A. D. Wright, R. Pukall, E. Stackebrandt, L. Eberl and K. Riedel, Appl. Environ. Microbiol., 2003, 69, 34693475 .

14 N. Lopanik, N. Lindquist and N. Targett, Oecologia, 2004, 139, 131139.

15 S. M. Al-Ogily and E. W. Knight-Jones, Nature, 1977, 265, 728.

16 P. J. Hayward and J. S. Ryland, Cheilostomatous Bryozoa Part 2. Hippothooidea-Celleporoidea, 2nd edn, Field Studies Council, Shrewsbury, 1999.

17 P. J. Hayward and J. S. Ryland, eds., The Marine Fauna of the British Isles and North-West Europe, Oxford Science Publications, Oxford, 1990.

18 M. Tischler, S. W. Ayer and R. J. Andersen, Comp. Biochem. Physiol., B: Biochem. Mol. Biol., 1986, 84, 43-45.

19 J. S. Carle and C. Christophersen, Toxicon, 1982, 20, 307-310.

20 J. S. Carle and C. Christophersen, J. Am. Chem. Soc., 1980, 102, $5107-$ 5108.

21 P. Bonnevie, Acta Allergol., 1948, 1, 40-46.

22 O. N. Pathmanaban, J. S. Porter and I. R. White, Clin. Exp. Dermatol., 2005, 30, 622-626.

23 M. L. Newhouse, Br. Med. J., 1966, 1, 1142-1145.

24 R. H. Seville, Br. J. Dermatol., 1957, 69, 92-93.

25 J. S. Porter, P. J. Hayward and M. E. S. Jones, J. Mar. Biol. Assoc U. K., 2001, 81, 1001-1008.

26 J. S. Porter, J. Mar. Biol. Assoc. U. K., 2004, 84, 243-252.

27 J. S. Porter, J. R. Ellis, P. J. Hayward, S. I. Rogers and R. Callaway, J. Mar. Biol. Assoc. U. K., 2002, 82, 529-535.

28 J. R. Ellis and S. E. Shackley, J. Fish Biol., 1997, 51, 361-372.

29 C. A. Gray, C. D. McQuaid and M. T. Davies-Coleman, Afr. J. Mar. Sci., 2005, 27, 549-556.

30 A. Sato and W. Fenical, Tetrahedron Lett., 1983, 24, 481-484

31 M. J. Ortega, E. Zubia and J. Salva, J. Nat. Prod., 1993, 56, 633-636.

32 I. Moubax, N. Bontemps-Subielos, B. Banaigs, G. Combaut, P. Huitorel, J. P. Girard and D. Pesando, Environ. Toxicol. Chem., 2001, 20, 589-596.

33 K. Konya, N. Shimidzu, K. Adachi and W. Miki, Fish. Sci. (Carlton, Aust.), 1994, 60, 773-775.

34 K. Nandakumar and M. Tanaka, Mar. Ecol.: Prog. Ser., 1994, 114, $157-163$.

$35 \mathrm{~J}$. Scholz and W. E. Krumbein, 10th International Bryozoology Conference, Wellington, New Zealand, 1996.

36 G. R. Pettit, Y. Kamano, R. Aoyagi, C. L. Herald, D. L. Doubek, J. M. Schmidt and J. J. Rudloe, Tetrahedron, 1985, 41, 985-994.

37 A. J. Blackman, T. P. D. Eldershaw and S. M. Garland, Aust. J. Chem., 1993, 46, 401-405.

38 H. P. Zhang, H. Shigemori, M. Ishibashi, T. Kosaka, G. R. Pettit, Y Kamano and J. Kobayashi, Tetrahedron, 1994, 50, 10201-10206.

39 C. K. Narkowicz, A. J. Blackman, E. Lacey, J. H. Gill and K. Heiland, J. Nat. Prod., 2002, 65, 938-941.

40 H. P. Zhang, Y. Kamano, H. Kizu, H. Itokawa, G. R. Pettit and C. L. Herald, Chem. Lett., 1994, 23, 2271-2274.

41 Y. Kamano, A. Kotake, H. Hashima, I. Hayakawa, H. Hiraide, H. P. Zhang, H. Kizu, K. Komiyama, M. Hayashi and G. R. Pettit, Collect. Czech. Chem. Commun., 1999, 64, 1147-1153.
42 H. P. Zhang, Y. Kamano, Y. Ichihara, H. Kizu, K. Komiyama, H. Itokawa and G. R. Pettit, Tetrahedron, 1995, 51, 5523-5528.

43 Y. Kamano, H. P. Zhang, Y. Ichihara, H. Kizu, K. Komiyama and G. R. Pettit, Tetrahedron Lett., 1995, 36, 2783-2784.

44 A. M. Montanari, W. Fenical, N. Lindquist, A. Y. Lee and J. Clardy, Tetrahedron, 1996, 52, 5371-5380.

45 G. R. Pettit, J. Nat. Prod., 1996, 59, 812-821.

46 B. D. Morris and M. R. Prinsep, J. Nat. Prod., 1999, 62, 688-693.

47 A. J. Blackman and R. D. Green, Aust. J. Chem., 1987, 40, 16551662.

48 A. J. Blackman and D. J. Matthews, Heterocycles, 1985, 23, 28292833.

49 A. J. Blackman and S. L. Fu, J. Nat. Prod., 1989, 52, 436-438.

50 J. T. Walls, A. J. Blackman and D. A. Ritz, J. Chem. Ecol., 1991, 17, 1871-1881.

51 J. T. Walls, A. J. Blackman and D. A. Ritz, Hydrobiologia, 1995, 297, $163-172$.

52 P. Bhadury and P. C. Wright, Planta, 2004, 219, 561-578.

53 J. S. Shellenberger and J. R. P. Ross, Northwest Sci., 1998, 72, 23-33.

54 N. K. Lee, W. Fenical and N. Lindquist, J. Nat. Prod., 1997, 60, $697-$ 699.

55 K. Konya, N. Shimidzu, K. Adachi and W. Miki, Fish. Sci. (Carlton, Aust.), 1994, 60, 773-775.

56 F. J. Schmitz, F. S. Deguzman, Y. H. Choi, M. B. Hossain, S. K. Rizvi and D. Vanderhelm, Pure Appl. Chem., 1990, 62, 1393-1396.

57 Y. H. Choi, A. Park, F. J. Schmitz and I. Vanaltena, J. Nat. Prod., 1993, 56, 1431-1433.

58 S. K. Rizvi, M. B. Hossain and D. Vanderhelm, Acta Crystallogr., Sect. C: Cryst. Struct. Commun., 1993, 49, 151-154.

59 A. J. Blackman, C. E. Ralph, B. W. Skelton and A. H. White, Aust. J. Chem., 1993, 46, 213-220.

60 A. J. Blackman, N. W. Davies and C. E. Ralph, Biochem. Syst. Ecol., 1992, 20, 339-342.

61 C. D. Harvell, Science, 1984, 224, 1357-1359.

62 C. D. Harvell, Ecology, 1992, 73, 1567-1576.

63 E. V. Iyengar and C. D. Harvell, Mar. Ecol.: Prog. Ser., 2002, 225, $205-218$.

64 J. S. Carle and C. Christophersen, J. Am. Chem. Soc., 1979, 101, 4012 4013.

65 J. S. Carle and C. Christophersen, J. Org. Chem., 1980, 45, 1586-1589.

66 J. S. Carle and C. Christophersen, J. Org. Chem., 1981, 46, 3440-3443.

67 C. Christophersen and J. S. Carle, Naturwissenschaften, 1978, 65, 440441.

68 P. B. Holst, U. Anthoni, C. Christophersen and P. H. Nielsen, J. Nat. Prod., 1994, 57, 997-1000.

69 P. B. Holst, U. Anthoni, C. Christophersen and P. H. Nielsen, J. Nat. Prod., 1994, 57, 1310-1312.

70 P. B. Holst, U. Anthoni, C. Christophersen, P. H. Nielsen and K. Bock, Acta Chem. Scand., 1994, 48, 765-768.

71 P. Keil, E. G. Nielsen, U. Anthoni and C. Christophersen, Acta Chem. Scand., Ser. B, 1986, 40, 555-558.

72 M. V. Laycock, J. L. C. Wright, J. A. Findlay and A. D. Patil, Can. J. Chem., 1986, 64, 1312-1316.

73 L. Peters, G. M. Konig, H. Terlau and A. D. Wright, J. Nat. Prod., 2002, 65, 1633-1637.

74 L. Peters, A. D. Wright, S. Kehraus, D. Gundisch, M. C. Tilotta and G. M. Konig, Planta Med., 2004, 70, 883-886.

75 L. Peters, A. D. Wright, A. Krick and G. M. Konig, J. Chem. Ecol., 2004, 30, 1165-1181.

76 J. L. C. Wright, J. Nat. Prod., 1984, 47, 893-895.

77 P. Wulff, J. S. Carle and C. Christophersen, J. Chem. Soc., Perkin Trans. 1, 1981, 2895-2898.

78 P. Wulff, J. S. Carle and C. Christophersen, Comp. Biochem. Physiol., B: Biochem. Mol. Biol., 1982, 71, 523-524.

79 P. Wulff, J. S. Carle and C. Christophersen, Comp. Biochem. Physiol., B: Biochem. Mol. Biol., 1982, 71, 525-526.

80 J. O. Schmidt, J. Apic. Res., 2001, 40, 7-10.

81 P. E. J. Dyrynda, in Bryozoa: Ordovician to Recent, eds. C. Nielsen and G. P. Larwood, Olsen and Olsen, Fredensborg, 1985, pp. 95-100.

82 N. A. Whitehead, A. M. L. Barnard, H. Slater, N. J. L. Simpson and G. P. C. Salmond, FEMS Microbiol. Rev., 2001, 25, 365-404.

83 M. Manefield, R. de Nys, N. Kumar, R. Read, M. Givskov, P. D. Steinberg and S. Kjelleberg, Microbiology, 1999, 145, 283-291.

84 U. Anthoni, L. Chevolot, C. Larsen, P. H. Nielsen and C. Christophersen, J. Org. Chem., 1987, 52, 4709-4712. 
85 L. Chevolot, A. M. Chevolot, M. Gajhede, C. Larsen, U. Anthoni and C. Christophersen, J. Am. Chem. Soc., 1985, 107, 4542-4543.

86 U. Anthoni, K. Bock, L. Chevolot, C. Larsen, P. H. Nielsen and C. Christophersen, J. Org. Chem., 1987, 52, 5638-5639.

87 A. J. Blackman, T. W. Hambley, K. Picker, W. C. Taylor and N. Thirasasana, Tetrahedron Lett., 1987, 28, 5561-5562.

88 L. Rahbaek, U. Anthoni, C. Christophersen, P. H. Nielsen and B. O. Petersen, J. Org. Chem., 1996, 61, 887-889.

89 L. Rahbaek and C. Christophersen, J. Nat. Prod., 1997, 60, 175-177.

90 G. R. Pettit, C. L. Herald, D. L. Doubek, D. L. Herald, E. Arnold and J. Clardy, J. Am. Chem. Soc., 1982, 104, 6846-6848.

91 G. R. Pettit, in Progress in the Chemistry of Organic Natural Products, eds. W. Herz, G. Kirby, W. Steglich and C. Tamm, Springer-Verlag, New York, 1991, vol. 57, pp. 153-195.

92 Z. Szallasi, K. Kosa, C. B. Smith, A. A. Dlugosz, E. K. Williams, S. H. Yuspa and P. M. Blumberg, Mol. Pharmacol., 1995, 47, 258-265.

93 M. G. Kazanietz, N. E. Lewin, F. Gao, G. R. Pettit and P. M. Blumberg, Mol. Pharmacol., 1994, 46, 374-379.

94 R. L. Berkow, L. Schlabach, R. Dodson, W. H. Benjamin, G. R. Pettit, P. Rustagi and A. S. Kraft, Cancer Res., 1993, 53, 2810-2815.

95 C. Scheid, J. Prendiville, G. Jayson, D. Crowther, B. Fox, G. R. Pettit and P. L. Stern, Cancer Immunol. Immunother., 1994, 39, 223-230.

96 M. L. Amador, J. Jimeno, L. Paz-Ares, H. Cortes-Funes and M. Hidalgo, Ann. Oncol., 2003, 14, 1607-1615.

97 A. Clamp and G. C. Jayson, Anti-Cancer Drugs, 2002, 13, 673-683.

98 K. J. Hale, M. G. Hummersone, S. Manaviazar and M. Frigerio, Nat. Prod. Rep., 2002, 19, 413-453.

99 N. Lopanik, K. R. Gustafson and N. Lindquist, J. Nat. Prod., 2004, 67, 1412-1414.

100 G. R. Pettit, F. Gao, P. M. Blumberg, C. L. Herald, J. C. Coll, Y. Kamano, N. E. Lewin, J. M. Schmidt and J. C. Chapuis, J. Nat. Prod., 1996, 59, 286-289.

101 G. R. Pettit, F. Gao, D. Sengupta, J. C. Coll, C. L. Herald, D. L. Doubek, J. M. Schmidt, J. R. Vancamp, J. J. Rudloe and R. A. Nieman, Tetrahedron, 1991, 47, 3601-3610.

102 G. R. Pettit, C. L. Herald and Y. Kamano, J. Org. Chem., 1983, 48 5354-5356.

103 G. R. Pettit, C. L. Herald, Y. Kamano, D. Gust and R. Aoyagi, J. Nat Prod., 1983, 46, 528-531.

104 G. R. Pettit, Y. Kamano and C. L. Herald, J. Nat. Prod., 1986, 49, 661-664.

105 G. R. Pettit, Y. Kamano and C. L. Herald, J. Org. Chem., 1987, 52, $2848-2854$.

106 G. R. Pettit, Y. Kamano, C. L. Herald and M. Tozawa, J. Am. Chem. Soc., 1984, 106, 6768-6771.

107 G. R. Pettit, Y. Kamano, C. L. Herald and M. Tozawa, Can. J. Chem., 1985, 63, 1204-1208.

108 G. R. Pettit, J. E. Leet, C. L. Herald, Y. Kamano, F. E. Boettner, L. Baczynskyj and R. A. Nieman, J. Org. Chem., 1987, 52, 2854-2860.

109 H. Lin, Y. Yi, W. Li, Y. Yao and H. Wu, Chin. J. Mar. Drugs, 1998, $17,1$.

110 D. E. Schaufelberger, G. N. Chmurny, J. A. Beutler, M. P. Koleck, A. B. Alvarado, B. W. Schaufelberger and G. M. Muschik, J. Org. Chem., 1991, 56, 2895-2900.

111 G. R. Pettit, D. L. Herald, F. Gao, D. Sengupta and C. L. Herald, J. Org. Chem., 1991, 56, 1337-1340.

112 G. N. Chmurny, M. P. Koleck and B. D. Hilton, J. Org. Chem., 1992, 57, 5260-5264.

113 D. E. Schaufelberger, M. P. Koleck, J. A. Beutler, A. M. Vatakis, A. B Alvarado, P. Andrews, L. V. Marzo, G. M. Muschik, J. Roach, J. T.
Ross, W. B. Lebherz, M. P. Reeves, R. M. Eberwein, L. L. Rodgers, R. P. Testerman, K. M. Snader and S. Forenza, J. Nat. Prod., 1991, 54, 1265-1270.

114 G. R. Pettit, D. Sengupta, C. L. Herald, N. A. Sharkey and P. M. Blumberg, Can. J. Chem., 1991, 69, 856-860.

115 D. Mendola, Biomol. Eng., 2003, 20, 441-458.

116 S. K. Davidson, S. W. Allen, G. E. Lim, C. M. Anderson and M. G. Haygood, Appl. Environ. Microbiol., 2001, 67, 4531-4537.

117 N. Lindquist, Mar. Biol., 1996, 126, 745-755.

118 N. Lindquist and M. E. Hay, Ecol. Monogr., 1996, 66, 431-450.

119 S. K. Davidson and M. G. Haygood, Biol. Bull., 1999, 196, 273-280.

120 R. G. Kerr, R. Vicchiarelli and S. S. Kerr, J. Nat. Prod., 1999, 62, 468-470.

121 G. R. Pettit, F. Gao, D. L. Herald, P. M. Blumberg, N. E. Lewin and R. A. Nieman, J. Am. Chem. Soc., 1991, 113, 6693-6695.

122 S. Matsunaga, N. Fusetani and K. Hashimoto, Experientia, 1986, 42, 84-84.

123 H. H. Wasserman, D. J. Friedland and D. A. Morrison, Tetrahedron Lett., 1968, 24, 641-644.

124 R. Kazlauskas, J. F. Marwood, P. T. Murphy and R. J. Wells, Aust. J. Chem., 1982, 35, 215-217.

125 A. J. Blackman and C. P. Li, Aust. J. Chem., 1994, 47, 1625-1629.

126 B. Carte and D. J. Faulkner, J. Org. Chem., 1983, 48, 2314-2318.

127 C. M. Yu and J. L. C. Wright, J. Nat. Prod., 1995, 58, 1978-1982.

128 D. J. Milanowski, K. R. Gustafson, J. A. Kelley and J. B. McMahon, J. Nat. Prod., 2004, 67, 70-73.

129 B. D. Morris and M. R. Prinsep, J. Org. Chem., 1998, 63, 95459547.

130 F. J. Schmitz and S. J. Bloor, J. Org. Chem., 1988, 53, 3922-3925.

131 A. J. Blackman, D. J. Matthews and C. K. Narkowicz, J. Nat. Prod., 1987, 50, 494-496.

132 J. A. Beutler, J. H. Cardellina, T. Prather, R. H. Shoemaker, M. R. Boyd and K. M. Snader, J. Nat. Prod., 1993, 56, 1825-1826.

133 M. R. Prinsep, J. W. Blunt and M. H. G. Munro, J. Nat. Prod., 1991, 54, 1068-1076.

134 D. T. Harwood, S. Urban, J. W. Blunt and M. H. G. Munro, Nat. Prod. Res., 2003, 17, 15-19.

135 F. Cafieri, E. Fattorusso, M. Gavagnin and C. Santacroce, J. Nat. Prod., 1985, 48, 944-947.

136 S. Eisenbarth, M. Gehling, A. Harder and B. Steffan, Tetrahedron, 2002, 58, 8461-8464.

137 N. R. Menon, Helgol. Wiss. Meeresunters., 1973, 25, 170-172.

138 M. Ojika, G. Yoshino and Y. Sakagami, Tetrahedron Lett., 1997, 38, 4235-4238.

139 T. Shindo, A. Sato, N. Kasanuki, K. Hasegawa, S. Sato, T. Iwata and T. Hata, Experientia, 1993, 49, 177-178.

140 S. J. Jeong, R. Higuchi, T. Miyamoto, M. Ono, M. Kuwano and S. F. Mawatari, J. Nat. Prod., 2002, 65, 1344-1345.

141 S. W. Ayer, R. J. Andersen, C. H. He and J. Clardy, J. Org. Chem., 1984, 49, 3869-3870.

142 J. S. Ryland, Bryozoans, Hutchinson \& Co., London, 1970

143 C. Burke, T. Thomas, S. Egan and S. Kjelleberg, Environ. Microbiol., 2006, 9, 814-818.

144 B. Carte and D. J. Faulkner, J. Chem. Ecol., 1986, 12, 795-804.

145 C. E. Salomon, N. A. Magarvey and D. H. Sherman, Nat. Prod. Rep., 2004, 21, 105-121.

146 M. Hildebrand, L. E. Waggoner, G. E. Lim, K. H. Sharp, C. P. Ridley and M. G. Haygood, Nat. Prod. Rep., 2004, 21, 122-142.

147 A. Waeschenbach, M. J. Telford, J. S. Porter and D. T. J. Littlewood, Mol. Phylogenet. Evol., 2006, 40, 195-207. 